\title{
Structure and kinematics of the northern Simano Nappe, Central Alps, Switzerland
}

\section{Journal Article}

\section{Author(s):}

Rütti, Roger; Maxelon, Michael; Mancktelow, Neil S.

Publication date:

2005-05

Permanent link:

https://doi.org/10.3929/ethz-b-000031691

\section{Rights / license:}

In Copyright - Non-Commercial Use Permitted

\section{Originally published in:}

Eclogae Geologicae Helvetiae 98(1), https://doi.org/10.1007/s00015-005-1148-7 


\title{
Structure and kinematics of the northern Simano Nappe, Central Alps, Switzerland
}

\author{
Roger Rütti $^{1}$, Michael Maxelon ${ }^{2} \&$ Neil S. Mancktelow ${ }^{2}$
}

Key words: Alpine tectonics, nappe tectonics, superposed folding

\begin{abstract}
New structural data allow the internal structure and kinematics of the Lower Penninic Simano Nappe to be established, together with the relationship of this unit to the underlying Leventina Gneisses and the also underlying Maggia Nappe. Three clearly distinguishable Alpine deformation phases (D1, D2, D3) are recognized within the Simano Nappe. D1 developed in mid-crustal levels under metamorphic conditions of ca. $1 \mathrm{GPa}$ and $500^{\circ} \mathrm{C}$ and produced kilometre-scale, recumbent, north-closing anticlinal folds, called nappes. During D2 these nappes were intensely refolded on the same scale and with identical style to form the present day recumbent fold pattern. The axial planar foliation S2 is the dominant planar fabric throughout most of the Central Alps. The subsequent phase D3 overprints the entire tectonostratigraphy of the Central Alps, with broader and more upright $\mathrm{D} 3$ folds trending oblique to the orogen. Regionally, these broad D3 folds have a major influence on the overall foliation and nappe outcrop pattern of the Central Alps. During D2 and D3, peak metamorphic conditions reached temperatures of up to $650^{\circ} \mathrm{C}$, under pressures of 0.7-0.8 GPa. An important consequence of this deformation history is that lithological units separated only by D2-synforms formed part of the same tectonostratigraphic level after D1 nappe-stacking and therefore should not be interpreted as different nappes. This principle can be directly applied to the relationship between the Simano and the two adjacent units. The underlying Leventina Gneisses are separated from the Simano rocks by an originally intrusive contact that has been strongly reactivated during both D1 and D2. Therefore, it is taken to represent a true nappe contact, although locally it still retains some original intrusive relationships and has also been strongly reactivated during D2. The Maggia and Simano units represent alternate limbs of a D2 synform-antiform pair, the Mogno synform and the Larecc antiform, or more generally the Verzasca-Larecc-Ganna antiform. If the Maggia unit is simply the continuation of the Simano unit around the D2 Mogno synform, then post-D1 they represented a single Simano-Maggia Nappe. The Maggia "Nappe" is therefore also part of the European margin and cannot be separately assigned to the Briançonnais paleogeographic domain, as has been proposed.
\end{abstract}

\section{ZUSAMMENFASSUNG}

Neue strukturelle Erkenntnisse erlauben es, nicht nur die interne Struktur und Kinematik der unterpenninischen Simano-Decke zu definieren, sondern auch die Beziehungen dieser Einheit mit den darunterliegenden Einheiten der Leventina-Gneise und der Maggia-Decke zu klären. Drei klar unterscheidbare alpine Deformationsphasen (D1, D2, D3) können innerhalb der SimanoDecke beobachtet werden. D1 entwickelte sich in mittelkrustalem Niveau unter Metamorphosebedingungen von etwa $1 \mathrm{GPa}$ und $500{ }^{\circ} \mathrm{C}$. Dabei wurden kilometergrosse, isoklinal nord-schliessende Antiklinalen gebildet, für welche sich die Bezeichnung "Decken" eingebürgert hat. Während D2 wurden diese Decken im gleichen Grössenbereich und mit identischem Faltungsstil wiederverfaltet und bildeten die prägenden deckenartigen Faltenstrukturen. Die achsenebeneparallele Schieferung S2 ist das dominierende Planargefüge. Sie kann in einem grossen Teil der Zentralalpen beobachtet werden. Die darauf folgende Deformationsphase D3 überprägte die gesamte Tektonostratigraphie der Zentralalpen mit offenen und aufrechten Falten, welche schräg zum grossräumigen Trend des Orogens verlaufen. Regional haben diese offenen D3 Falten einen grossen Einfluss auf die regionale Schieferung und das regionale Aufschlussmuster in den Zentralalpen. Während D2 und D3 erreichte die Metamorphose maximale Bedingungen von bis zu $650{ }^{\circ} \mathrm{C}$ bei Drücken von 0.7-0.8 GPa. Ein wichtige Konsequenz dieser Deformationsgeschichte besteht nun darin, dass lithologische Einheiten, die nur durch D2-Synformen getrennt sind, Teile des gleichen lithostratigraphischen Niveaus nach der D1-Deckenbildung sind und darum nicht als unterschiedliche Decken interpretiert werden sollten. Dieses Prinzip kann direkt auf die Beziehungen zwischen der Simano-Decke und zwei benachbarten Einheiten angewendet werden. Die sich im Liegenden befindlichen Leventina-Gneise sind von der Simano-Decke durch einen ursprünglich intrusiven Kontakt voneinander getrennt, welcher dann während D1 und D2 stark reaktiviert wurde. Diesen Kontakt interpretieren wir als eigentlichen Deckenkontakt, welcher noch immer einige ursprüngliche Intrusivbeziehungen zeigt und während D2 sehr stark reaktiviert wurde. Die Maggia und Simano Einheiten stellen zwei verschiedene Schenkel eines D2-Synform/Antiform-Paares dar: das der Mogno-Synform und der Larecc-Antiform, oder allgemeiner der Verzasca-Larecc-Ganna-Antiform. Wenn nun die Maggia-Einheit die Fortsetzung der Simano-Einheit um die D2 Mogno-Synform ist, dann repräsentieren beide Einheiten post-D1 eine einzelne (Simano-Maggia-) Decke. Die Maggia-Decke ist Teil des passiven Europäischen Kontinentalrandes und kann folglich nicht zum Briançonnais gezählt werden.

\footnotetext{
${ }^{1}$ Institute for Mineralogy and Petrography, ETH Zurich, Sonneggstrasse 5, 8092 Zurich, Switzerland. E-mail: roger.ruetti@erdw.ethz.ch; present address: Schweizerische Geotechnische Kommission, ETH-Zentrum, 8092 Zurich, Switzerland.

${ }^{2}$ Geological Institute, ETH Zurich, Sonneggstrasse 5, 8092 Zurich, Switzerland.
} 


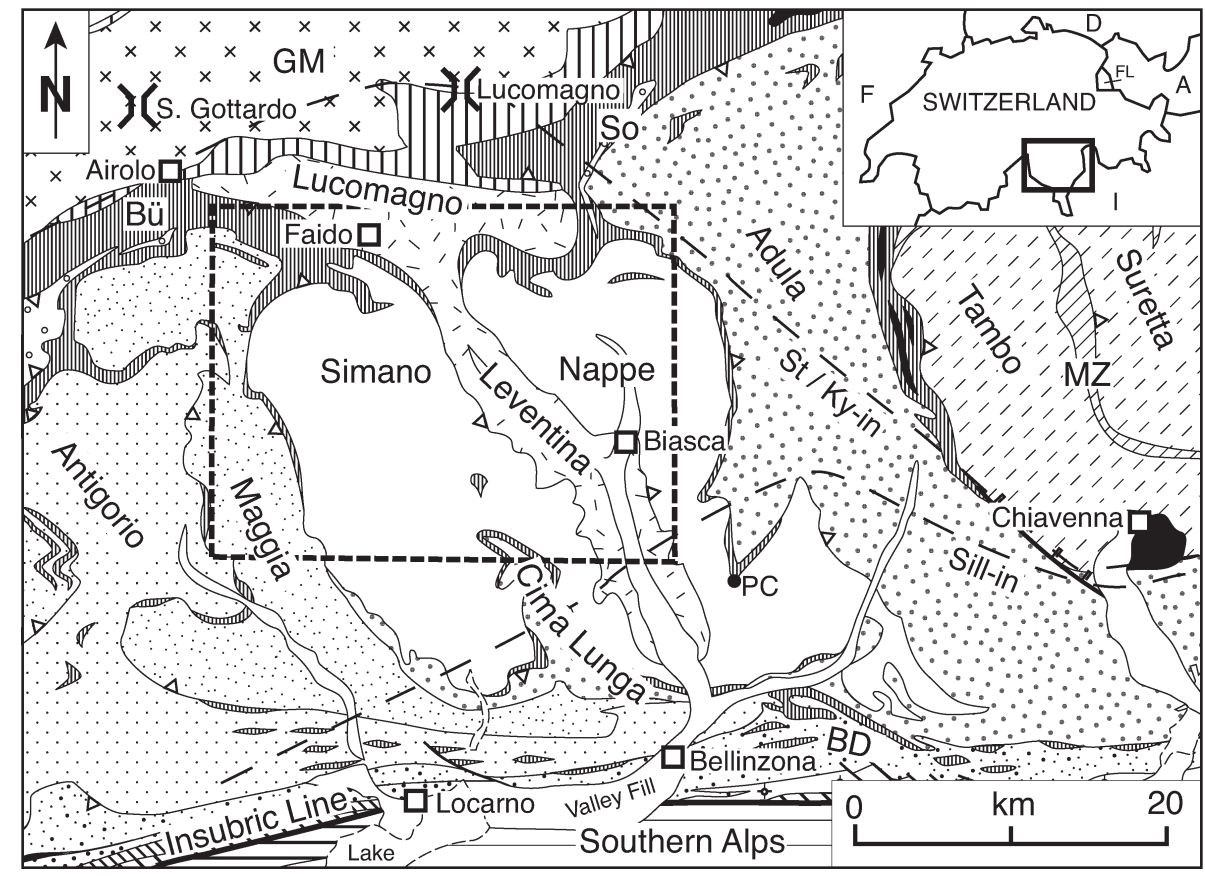

Fig. 1. Map of the Central Alps of Switzerland modified after Spicher (1980). The study area is bounded by the dashed line. The staurolite/kyanite-in and sillimanite-in isograds are from Niggli and Niggli (1965) and Thompson (1976). Abbreviations: $\mathrm{BD}=$ Bellinzona-Dascio Zone, $\mathrm{Bü}=$ Bündnerschiefer, $\mathrm{GM}=$ Gotthard Massif, $\mathrm{MZ}=$ Zone of Misox and Splügen, $\mathrm{PC}=$ Pizzo di Claro, So $=$ Soja Zone. Solid black: Ultramafic bodies or units.

\section{Introduction}

The Central Alps of Switzerland (Fig. 1) are the classic area for fold nappe tectonics in mid-crustal levels. Despite the long tradition of geological research in this region and a correspondingly large number of relevant publications, some important issues with regard to the location and significance of contacts between major tectonic units remain unresolved. This is the case with both the upper and lower contacts of the Simano Nappe.

It was recognized quite early that the geometry of the Central Alps is the result of complex folding of pre-Triassic basement and its Mesozoic cover during the Alpine orogeny (Gerlach, 1869; Schmidt, 1894; Schardt, 1906). Large north-closing antiforms with basement cores and envelopes of Mesozoic carbonate sedimentary rocks were defined as nappes and named after type localities (Schmidt \& Preiswerk, 1908; Argand, 1911; Heim, 1919-1922; Staub, 1924). The present nappe nomenclature of the Central Alps is mainly based on work from the beginning of the 20th century (Preiswerk, 1918a, b, 1921; Jenny et al., 1923; Preiswerk et al., 1934). These early studies culminated in the still most relevant geological map of the region (compiled by Preiswerk et al., 1934; simplified version in Fig. 2) and were extensively discussed in Niggli et al., 1936). The inherent complexity of the Central Alps is illustrated by the range of different tectonic schemes that had already been proposed at that time and which were compared and contrasted in Niggli et al. (1936).

One of the controversies that has remained unresolved since that time is the relative position of the Simano Nappe and its relationship with two of its adjacent units, namely the Leventina Gneisses and the Maggia Nappe (Fig. 1). Bossard (in Niggli et al., 1936) postulated that the Leventina Gneisses form an independent nappe. This interpretation, supported also by Casasopra (1939), is based on isolated outcrops of quartz-rich rocks of supposedly Triassic age ("Triassic Quartzites") between the Simano Nappe and the Leventina Gneisses. However, the locally discordant relationship between the two units can be used as evidence for an originally intrusive relationship between the Leventina (Ortho-) Gneisses and the (predominantly) paragneisses and schists of the Simano (e.g. Fig. 2). In this study, the relationship between the Simano Nappe and the Leventina Gneisses has been investigated, with the aim of establishing whether this contact is truly a nappe boundary (i.e. a thrust related to the first Alpine deformation phase) or whether it represents an already existing pre-Alpine intrusive contact, in part reactivated during Alpine deformation.

The boundary of the Simano Nappe with the Maggia Nappe is closely associated with another controversial structure in the Central Alps: the Maggia Steep Zone or Maggia Crossfold ("Querfalte" of Preiswerk, 1921), which is still subject to differing interpretation. Steck (1998) considers the Maggia Nappe to lie within a synformal structure associated with this cross-folding. This would be consistent with a regional model placing the Maggia Nappe high in the tectonostratigraphic sequence and thus potentially derived from the Briançonnais paleogeographic domain, as suggested by Froitzheim et al. (1996) and Schmid et al. (2004). In contrast, Grujic \& Mancktelow (1996) considered the Maggia Nappe to represent an earlier structure now lying on one steep limb (the "steep zone") of the crossfolding structure and originally derived from the European margin. 
This paper presents new observations on the internal structure of the Simano Nappe as well as observations from the boundaries with both the Leventina Gneisses and the Maggia Nappe (Fig. 1). The correct interpretation of these field relationships has important implications for the tectonostratigraphic position of all three units within the general structure of the Lower Penninic zone, and therefore for any regional tectonic model of the Central Alps.

\section{Geological setting}

\subsection{Simano Nappe}

The Simano Nappe is a large basement nappe outcropping between Valle Maggia and Valle Mesolcina (Fig. 1). It is made up of several orthogneiss bodies of Caledonian and Hercynian age intruded into paragneisses and schists, and locally originally overlain by probable (now metamorphic) Permo-Carboniferous quartz-rich and polymict conglomerates, quartzites, and shales (Jenny et al., 1923; Niggli et al., 1936; Keller, 1968; Köppel \& Grünenfelder, 1975; Codoni, 1981). Paleogeographically this nappe belongs to the southern passive margin of the European plate prior to Alpine collision. Especially the frontal (i.e. northern) parts of the nappe now consist predominantly of semipelitic to pelitic gneisses and mica schists, intercalated with numerous amphibolite lenses (Keller, 1968; Bianconi, 1971; Irouschek, 1983). Two occurrences of larger ultramafic bodies have also been reported and described (Hezner, 1909; Preiswerk et al., 1934; Schaltegger et al., 2002). Alpine metamorphic conditions in the unit gradually increase from lower amphibolite facies in the northern parts to upper amphibolite facies conditions in the south (e.g. Frey et al., 1974, 1976; Engi et al., 1997). Evidence for a high-pressure metamorphic event equivalent to that recorded in the overlying Adula-Cima Lunga Unit (e.g. Heinrich, 1986) has not been found to date (Irouschek 1983, Keller, 1968, Rütti, 2001, 2003). In the north, several distinct horizons of Mesozoic metasedimentary rocks separate the Simano Nappe from the over- and underlying units. However, toward the south, outcrops of these rocks become scarce and finally disappear, rendering the distinction between the units ambiguous and debatable.

\subsection{Leventina Gneisses}

The Leventina Gneisses are normally interpreted as the structurally deepest rocks exposed in the Central Alps of Switzerland (Fig. 1; e.g. Spicher, 1980). The orthogneiss body has a trondhjemitic-leucocratic bulk composition (Casasopra, 1939, 1948a, b, 1953) and intrusion was in Hercynian time (Allègre et al., 1974; Köppel et al., 1980; Köppel, 1993). In the north, the unit is separated by Mesozoic metasediments from preMesozoic metasediments of the Lucomagno Unit (Bianconi, 1971) and from the Simano Nappe by metasediments whose Mesozoic age has been presumed (Niggli et al., 1936; Bianconi 1971), but remains unproven. Toward the south, these metasediments are rare and the boundary has to be defined by other criteria. The lower boundary of the Leventina Gneisses may be represented by an anhydrite-bearing zone from the subsurface that was described by Hiss (1975). Casasopra (1939) described a strongly deformed (i.e. mylonitic) horizon representing the boundary between the Leventina Gneisses and the Simano Nappe in this southern region, an observation that was confirmed by Irouschek (1983), Merle et al. (1989), Rütti (2003) and Timar-Geng et al. (2004). To the north, the Lucomagno Nappe has been interpreted as representing the metasedimentary country rock into which the Leventina Gneisses were intruded and these two units are therefore generally referred to as the Lucomagno-Leventina Nappe (Fig. 1; Milnes, 1976; Spicher, 1980; Etter, 1992).

\subsection{Maggia Nappe}

The Maggia Nappe is exposed from Val Bedretto in the north to Lago Maggiore in the south, varying in east-west extent from less than $1 \mathrm{~km}$ up to $15 \mathrm{~km}$ (Fig. 1). The unit consists of three distinct orthogneissic bodies (Cocco and Ruscada on Fig. 2, and Matorello further NW) within dominantly paragneissic assemblages (Buchmann, 1953; Günthert, 1954; Keller, 1968; Keller et al., 1980; Klaper, 1982; Simpson, 1982; Günthert et al., 1996). Although the Maggia Nappe has been studied in detail over a long period, its tectonostratigraphic position (European or Briançonnais domain) is still a matter of debate (Froitzheim et al., 1996; Grujic \& Mancktelow, 1996; Steck, 1998; Schmid et al., 2004; Maxelon \& Mancktelow, in press).

The Maggia Nappe is closely associated with the Maggia Steep Zone, which forms an important zone of roughly NWSE-trending steep foliation and separates two major domes in the regional foliation - the Simplon or Toce dome to the west and the Ticino or Leventina dome to the east (e.g. Merle et al, 1989). In the past, this steep zone has been explained either as an "obliquely trending root zone" (Kündig, 1936) or as a major synform with the Maggia Nappe in its core and therefore tectonostratigraphically above the Simano Nappe (Niggli et al., 1936). Huber et al. (1980), in considering the deformation phases observed in the area, implied as an aside that the Maggia Nappe is tectonically interposed between the Simano Nappe above and the Antigorio Nappe below. Grujic \& Mancktelow (1996) were the first to state explicitly that the Maggia Nappe does not represent a synform related to the crossfolding but rather that its current position coincides with a pronounced monoclinal steep zone - the Maggia Steep Zone. However, this interpretation remains controversial and several authors have reiterated the synformal model for the Maggia Nappe (e.g. Merle \& Le Gal, 1988; Steck, 1998). In the area considered here, the Maggia Nappe lies tectonically below the Simano Nappe. However, in the Bellinzona region further to the south, the Maggia Nappe is in a tectonic position above the Cima Lunga Unit, which in turn overlies the Simano Nappe. This relationship (i.e. Maggia Nappe above Cima Lunga Unit) 


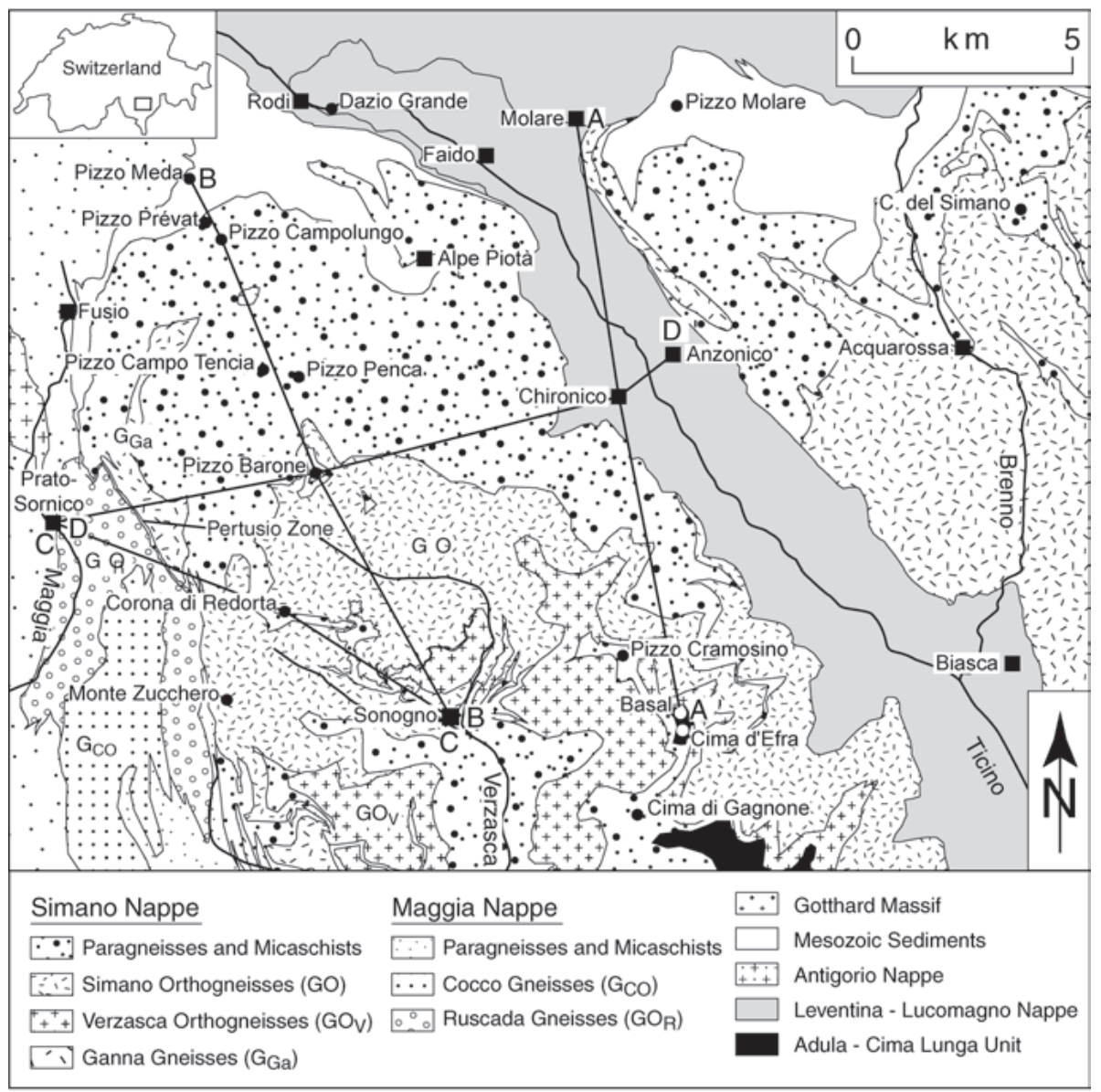

Fig. 2. Simplified version of the map of Preiswerk et al. (1934). Some parts of the map have been modified according to the map of Keller (1968; Map 1:25’000 1272 Pizzo Campo Tencia). Squares indicate villages and circles indicate mountain peaks. has been cited as evidence for assigning the Maggia Nappe to the Briançonnais paleogeographic domain (e.g. Froitzheim et al., 1996), but alternative models have been proposed recently (Maxelon and Mancktelow, in press).

\section{Deformation phases}

\subsection{Introduction}

Trajectories of the main foliation and lineation for the Central Alps were published by Wenk $(1955,1956)$ and Keller (1968) and these trajectory maps clearly outline a complex pattern of interfering fold phases postdating the main foliation. However, it was the pioneering work in $\mathrm{PhD}$ theses from Imperial College, London (e.g. Higgins, 1964; Thakur, 1971, 1973; Hall, 1972) that really established the concept of geometrically distinct deformation phases in the Central Alps, as subsequently summarized in Ayrton \& Ramsay (1974), Milnes (1974a, b) and many others since then. Grujic \& Mancktelow (1996) presented a model for the northern Maggia Nappe involving five phases of deformation (D1 to D5) that were recognized and correlated over a large region. Comparable deformation phases have also been found in other units of the Central Alps, such as the Tambo Nappe (Marquer, 1991; Baudin et al., 1993), the Simano Nappe (Grond et al., 1995; Partzsch, 1998; Pfiffner, 1999; Rütti, 2001; Nagel et al., 2002) and the Adula-Cima Lunga Unit (Baumgartner \& Löw, 1983; Löw, 1987; Meyre \& Puschnig, 1993; Nagel et al., 2002), although the numbering system of deformation phases does not necessarily correspond. The same basic scheme was also recognized in the current study and the characteristics of the different phases, and the associated microstructures, are described below.

\subsection{Deformation phase D1}

Field observations

Structures related to the first deformation phase D1 are only observed in a few outcrops in the investigated area. The subsequent strong overprinting during D2 has obliterated most D1 features. This observation is consistent with earlier studies (Huber et al., 1980; Simpson, 1982; Grujic \& Mancktelow, 1996) in neighbouring regions in the Central Alps. D1 generated regional isoclinal folds with cores of pre-Triassic basement, which are commonly surrounded by strongly stretched Mesozoic metasediments (Bianconi, 1971). 

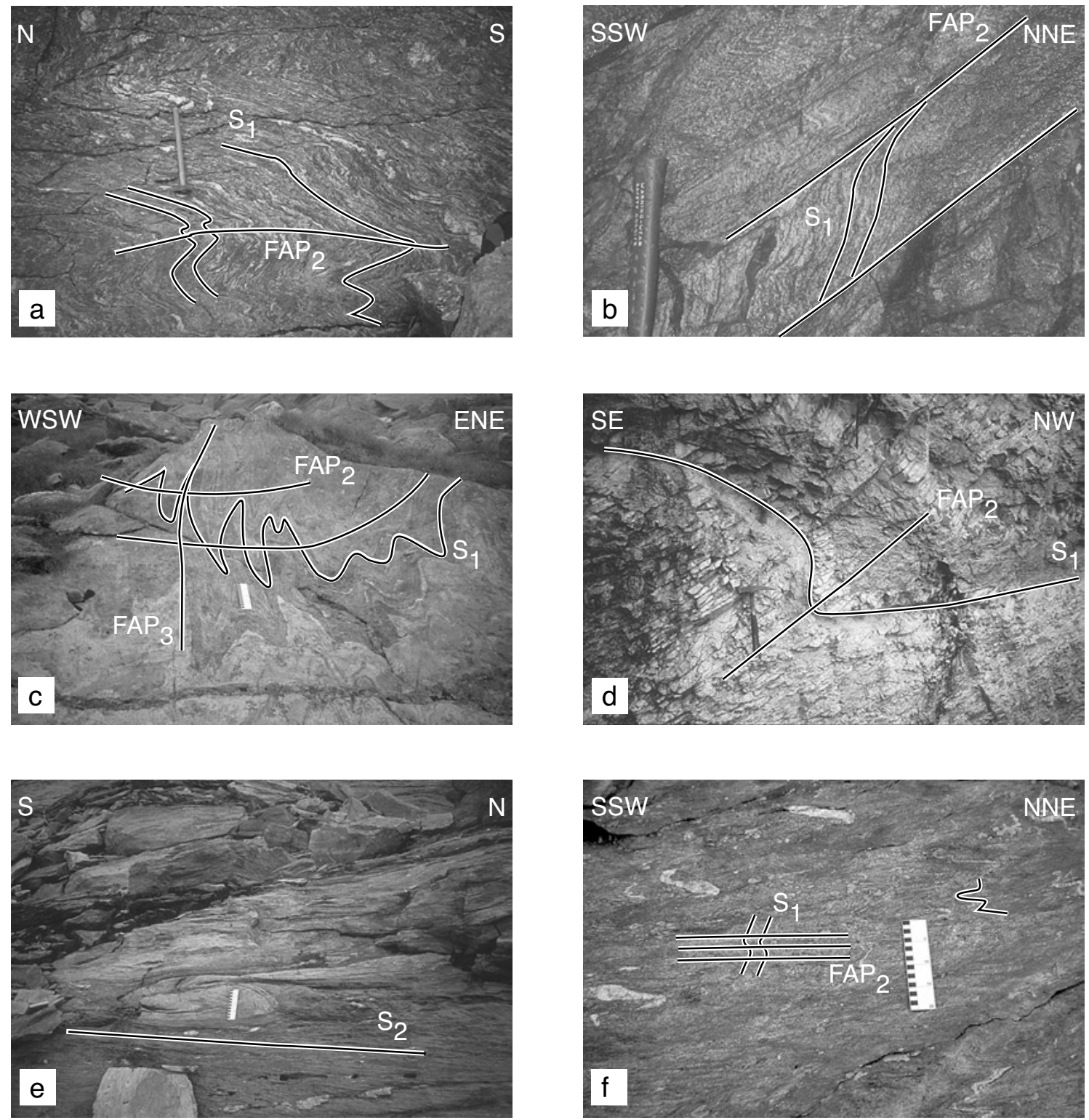

Fig. 3. Field photographs of structural features observed in the Simano Nappe. a) $D^{1 /} \mathrm{D}^{2}$ interference in a large $\mathrm{D}^{2}$ fold hinge showing parasitic $\mathrm{M}$-folds, southeast of Capanna di Leit (Swiss Coordinates 699000/146040). b) $\mathrm{D}^{1} / \mathrm{D}^{2}$ interference in orthogneiss in the Dazio Grande gorge (Swiss coordinates 700883/149665). c) Outcrop showing the interference of deformation phases $\mathrm{D}^{1}-\mathrm{D}^{3}$ and the folded contact between two types of gneisses (region of Alpe Sponda, Swiss coordinates 702000/142810). d) Example of relict refolded $\mathrm{D}^{1}$-structures within the regionally dominant foliation $\mathrm{S}^{2}$ in metacarbonates of the Mesozoic cover of the Simano Nappe in Val Blenio (Swiss coordinates 712672/147816). e) Isoclinal folds with extreme thickening of the fold hinges developed during $\mathrm{D}^{1}$ and now transposed into $\mathrm{S}^{2}$ (north of Pizzo Barone, Swiss coordinates 700700/140420). f) Rheologically more competent rock types, such as semi-pelites and/or metagranitic rocks, show a lesser degree of deformation and have preserved $\mathrm{D}^{1}-\mathrm{D}^{2}$ interference patterns (region of Alpe Sponda, Swiss coordinates 703040/142470).

Structural elements of the first and second phases of deformation are generally subparallel. As a result, unequivocal D1 features are only discernable in the fold hinges of larger D2 structures (Fig. 3a). In the Leventina Gneisses, D2 folds have locally been observed folding an earlier foliation (e.g. in the Dazio Grande gorge, SwissGrid coordinates 700883/149665, Fig. 3b). This implies that the main foliation in this orthogneiss was initially formed during D1 but subsequently accentuated by the strong regional deformation phase D2. D1 itself overprints older structures such as bedding and/or banding in the gneisses (e.g. Fig. 3a, c). In most studied outcrops, D1 structures are only present as relicts within the regionally dominant foliation S2, for example as refolded folds in metacarbonates of the Mesozoic cover of the Simano Nappe in Val Blenio (Fig. 3d; SwissGrid Coordinates 712672/147816). In the area consisting mainly of pre-Alpine metasedimentary rocks between 

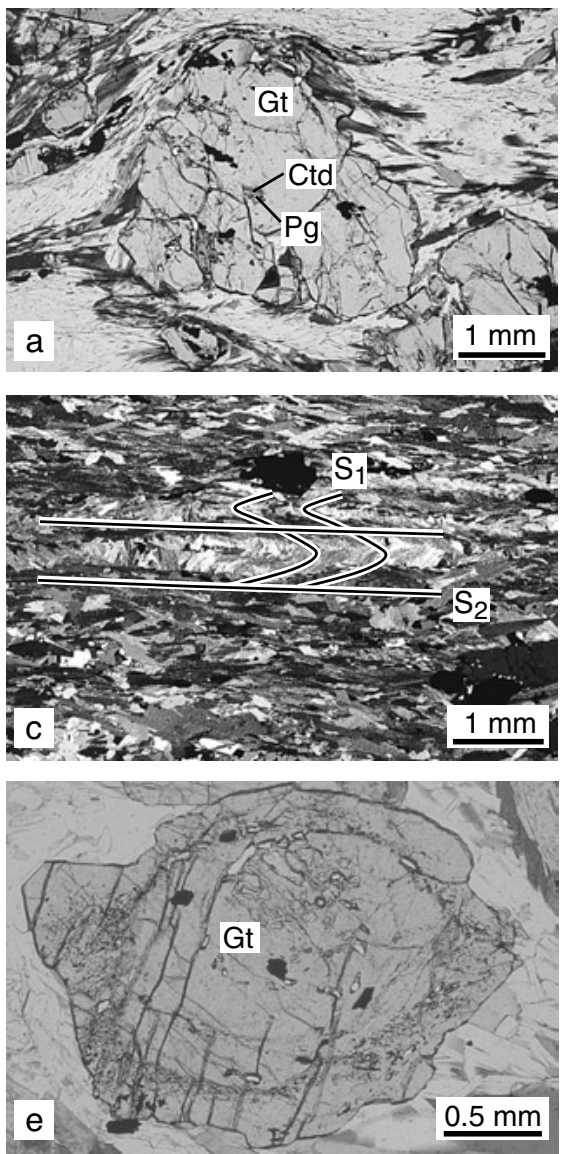
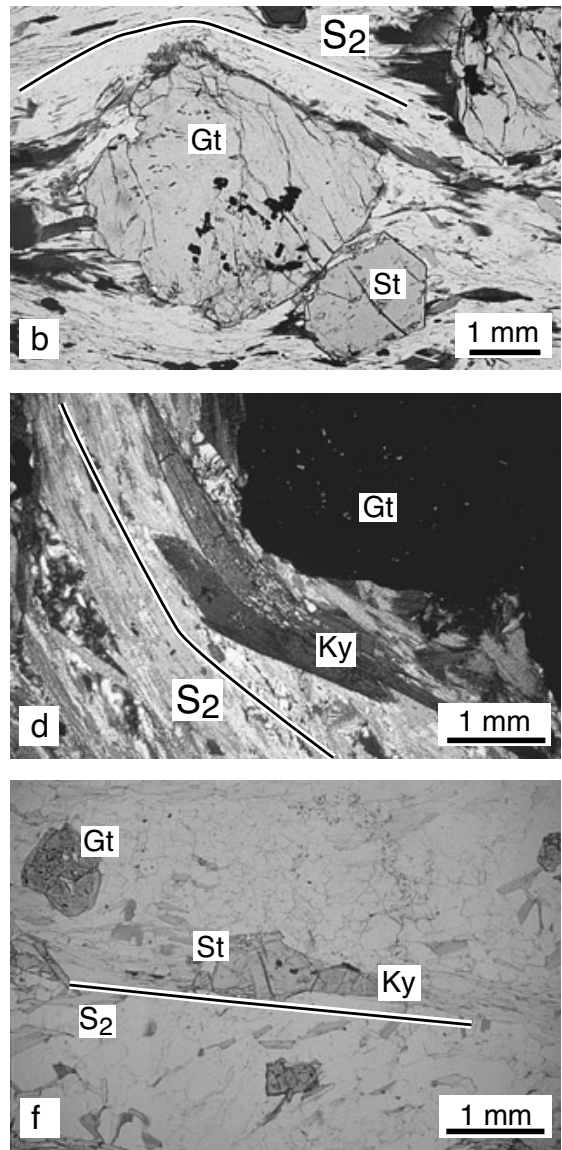

Fig. 4. Microphotographs of metapelites in the northern Simano Nappe. a) Garnet porphyroblast in sample LEV25 with inclusions of chloritoid and paragonite. These inclusions allow the early stages of the main Alpine metamorphic event to be constrained (see Rütti, 2003). b) Subhedral garnet grain in sample LEV25. The main foliation $\mathrm{S}^{2}$ is bent around the garnet porphyroblast, but the inclusions in the garnet show the same direction and therefore the garnet has grown syn- $\mathrm{D}^{2}$. The staurolite in this microphotograph has also grown syn- $\mathrm{D}^{2}$. c) Recrystallized crenulation fold hinges outlined by white micas in sample LEV25, proving that the main foliation $\mathrm{S}^{2}$ is a second foliation in these rocks. d) Deformed kyanite crystals in sample CT9. Kyanite grains are bent around the large garnet porphyroblast and have grown pre- to syn- $\mathrm{D}^{2}$. e) Garnet porphyroblast showing a growth rim in sample CT1. This growth rim is separated from the presumably pre-Alpine core by a narrow zone where many inclusions are found. f) Intergrowth of staurolite and kyanite during $\mathrm{D}^{2}$, with these minerals aligned parallel to the main foliation $\mathrm{S}^{2}$.
Passo Campolungo and Pizzo Forno, relict D1 structures are locally preserved as small-scale features, such as intrafolial folds within the dominant foliation. Depending on the rheological properties of the rocks, close to isoclinal folds, sometimes with extreme thickening of the fold hinges, were developed during D1 (Fig. 3e). Rheologically more competent rock types, such as semi-pelites and/or metagranitic rocks, show a lesser degree of deformation and more commonly preserve D1-D2 interference patterns (Fig. 3f).

\section{Microstructures}

In the metapelites of the Simano Nappe, two generations of garnet are observed. The older generation consists of large porphyroblasts (on the order of $1-2 \mathrm{~cm}$ in diameter) whose core is probably of pre-Alpine age. In such garnets, only the outermost rim has grown during the main Alpine metamorphic event of the Central Alps. This outermost rim is often separated from the older core by a zone of inclusions. The outermost rim does not contain any, or only very few, inclusions. The younger generation of garnet often has a subhedral to euhedral form (Fig. 4b) and has grown entirely during the main Alpine metamorphic event. Some garnets also show resorption, which is attributed to later retrograde stages of the tectono-metamorphic history. In the core of such garnets, in- clusions of chlorite, chloritoid and paragonite have been found (Fig. 4a). These inclusions indicate P-T conditions of ca. 1.1-1.3 $\mathrm{GPa}$ and $500^{\circ} \mathrm{C}$ (Rütti, 2003), which may reflect either the preor early Alpine environment. Other inclusions in these garnets are muscovite and biotite. Pre-D2 kyanite is folded around some of the large garnet porphyroblasts (Fig. 4d). The stable assemblage during this deformation phase is chlorite, chloritoid, paragonite, zoisite, quartz and chlorite, and in Al-rich metapelites the stable mineral assemblage consists of chloritoid, paragonite, zoisite, quartz and kyanite (Rütti, 2003).

\subsection{Deformation phase D2}

\section{Field observations}

D2 affects the already existing nappe pile and formed large, recumbent isoclinal folds ("main Alpine folding" or "main post-nappe folding" of Milnes, 1974a, b). The associated foliation S2 developed parallel to the D2 fold axial planes and forms the dominant regional planar fabric. It has often been referred to as the "main Alpine foliation" in early structural studies (e.g. Wenk, 1948, 1955, 1956). In the limbs of D2-folds, $\mathrm{S} 2$ is effectively parallel to the older foliation S1 and the resulting foliation is then a composite of both S1 and S2. How- 


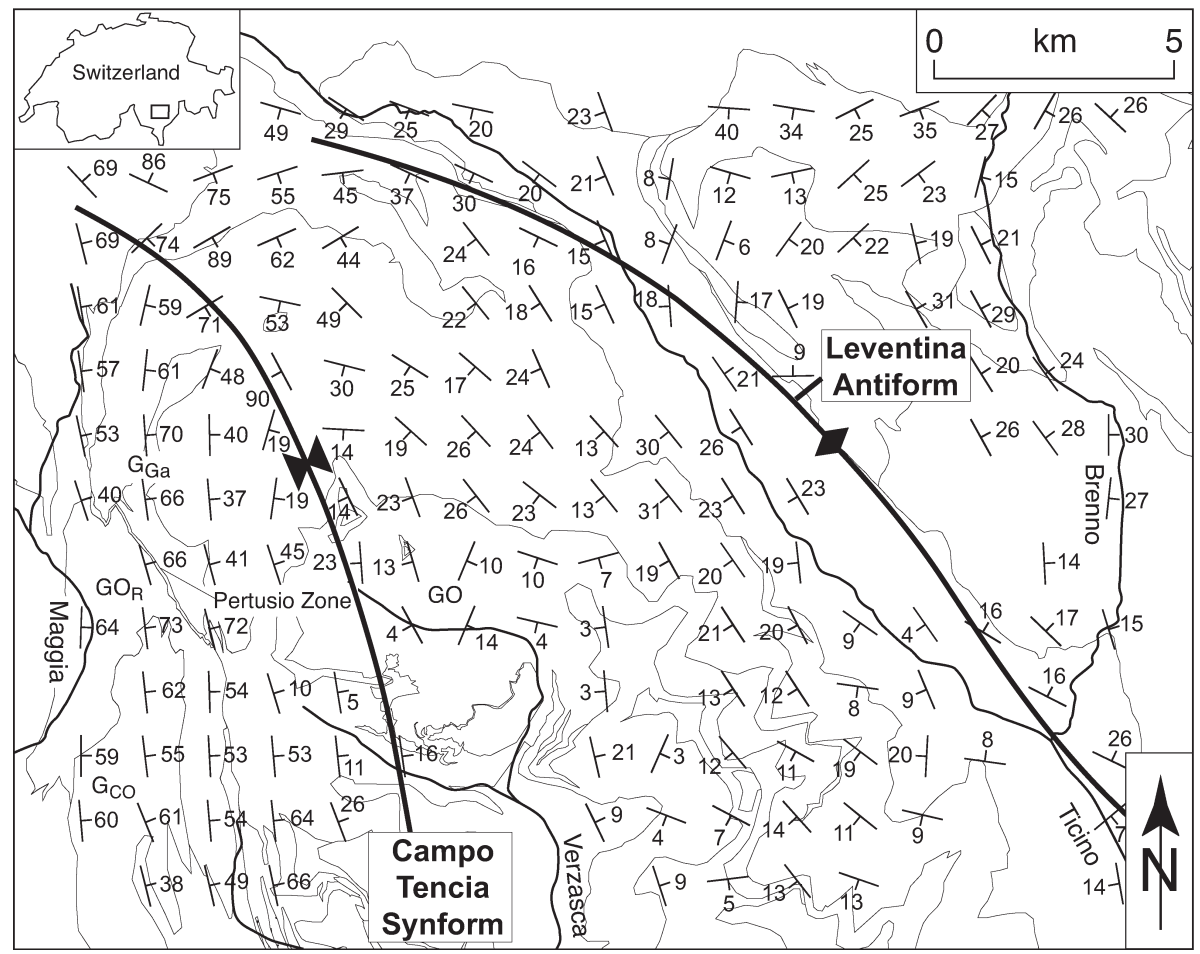

Fig. 5. Map of $\mathrm{S}^{2}$ foliations in the study area. 2016 field measurements of $\mathrm{S}^{2}$ were averaged through inverse distance weighted spatial averaging with the program SpheriStat. The spacing between two points measures $1.5 \mathrm{~km}$. The $\mathrm{D}^{3}$ Campo Tencia synform and the $\mathrm{D}^{3}$ Leventina antiform are indicated for reference. ever, in D2 fold hinges a discordant relationship between S1 and $\mathrm{S} 2$ can still be observed. In such cases, S2 may be quite weak and the dominant foliation is not uncommonly S1 (Fig. 3a). S2 generally dips with 20 to $30^{\circ}$ towards WSW west of the ridge between Valle Leventina and Val Blenio and more steeply to the ENE east of this ridge (Fig. 5). The S2 patterns change from south to north. In the south, in the region of Pizzo Barone, the main foliation S2 is dominantly flat-lying and strike measurements are therefore very variable. In the north, the main foliation S2 has been affected by later deformation phases. In particular, the earlier structures have been steepened around a regional synform in the northernmost part of the Simano Nappe (see top of Fig. 5) to form the "Northern Steep Belt" of Milnes (1974b). This synform has been called the Chiéra Synform (Milnes, 1976; Etter, 1992) and was assigned to the regional D4 deformation phase in the scheme of Grujic \& Mancktelow (1996).

On the S2 foliation plane, a more or less strongly developed lineation L2 is observed, generally related to stretching of quartz and feldspars in gneisses and schists. The L2 lineation in all rock types plunges gently to the SE to SSE (Fig. 6). In the region of Alpe Sponda, the L2 lineation is often clearly oblique to the FA2 fold axes. Fold axes FA2 in this region are dispersed within the S2 axial plane foliation, with directions varying between N-S and NW-SE (Fig. 7), reflecting in part the pre-structuration of the basement prior to Alpine deformation. This observation is in contrast to the parallelism between lineations and fold axes of the second phase of deformation that is often described in the Central Alps (Milnes, 1974a; Huber et al., 1980; Simpson, 1981; Baudin et al., 1993; Grond et al., 1995; Pfiffner, 1999).

The combined effect of the deformation phases D1 and D2 on the underlying Leventina Gneisses is reflected in the grain size of the gneisses. Deformation during D2 was locally very intense (Figs. 8, 9). Fine-grained varieties of the Leventina Gneisses are associated with a penetrative main foliation (the composite of S1 and S2), reflecting the extensive dynamic recrystallization and grain size reduction during D2 and most likely already during D1. The more coarse-grained varieties show neither a strong D1 nor a remarkable D2 overprint and in some outcrops feldspar clasts were only partially rotated into the orientation of the main foliation. The deformation was most intense in the contact zone between the Simano Nappe and the Leventina Gneisses, where a 50-200 m wide mylonitic horizon is observed.

Many macro- and microscopic shear sense indicators can be observed in the study area. Boudinaged calc-silicate nodules indicate a NW-SE stretching direction for D2 with a shear sense top-to-NW (Fig. 8a; SwissGrid Coordinates 702670/142060). In the mylonitic horizon between the Leventina Gneisses and the Simano Nappe and immediately adjacent to this zone, top-to-NW senses of shear are frequently observed and interpreted as due to D2 (Fig. 8b, c). This sense of shear is in contrast to observations in the southern parts of the Simano Nappe, where top-to-SE senses of shear are reported in the vicinity of the boundary with the Adula Nappe (Rütti, 2001) and the Cima Lunga Unit (Grond et al., 1995; Pfiffner, 1999; Giger, 2000; Nagel et al., 2002). 


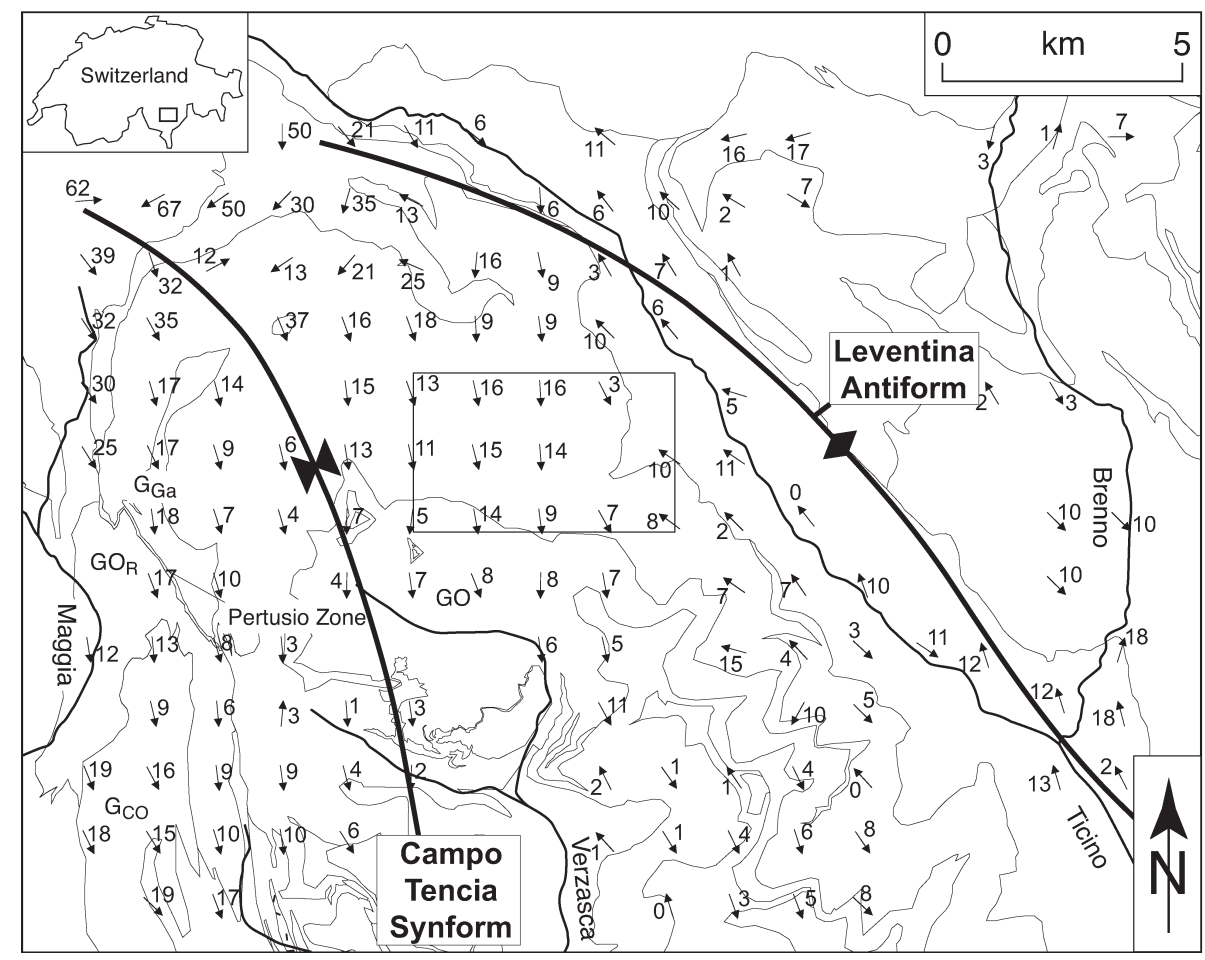

Fig. 6. Map of $\mathrm{L}^{2}$ lineations in the study area. 933 field measurements of $\mathrm{L}^{2}$ were averaged through inverse distance weighted spatial averaging with the program SpheriStat. The spacing between two points measures $1.5 \mathrm{~km}$. The $\mathrm{D}^{3}$ Campo Tencia synform and the $\mathrm{D}^{3}$ Leventina antiform are indicated for reference. The frame denotes the outline of Fig. 7.

\section{Microstructures}

The S2 foliation in Al-rich gneisses and schists is characterized by synkinematic growth of biotite, muscovite/paragonite, kyanite, staurolite and garnet. Quartz and feldspars are deformed and dynamically recrystallized. In many samples, crenulation fold hinges can be observed, confirming that the main foliation corresponds to a second foliation in these rocks (Fig. 4c). Staurolite and kyanite, which are commonly intergrown, lie within the main foliation S2 (Fig. 4f). According to Spear (1993), this intergrowth corresponds to the reaction staurolite + chlorite $=$ biotite + kyanite $+\mathrm{H}_{2} \mathrm{O}$. Garnet grows either as euhedral grains or as rims on a presumably pre-Alpine garnet core. This rim growth around garnet porphyroblasts (Fig. 4e) may be attributed to D2 and/or D3. The main foliation consisting of white and dark micas is bent around the large porphyroblasts of garnet (Fig. 4b), consistent with the existence of pre-D2 (and probably also pre-Alpine) garnet cores. The stable mineral assemblage during D2 is muscovite, biotite, plagioclase and quartz, with varying amounts of kyanite, staurolite and garnet.

Two generations of staurolite are observed in Al-rich metapelites. The earlier one is found within the dominant foliation S2 (Fig. 4f) and is part of the stable assemblage chlorite, staurolite, paragonite, garnet, muscovite and quartz. These staurolite grains were then resorbed to form more garnet and metamorphic conditions during D2 attained temperatures as high as $650^{\circ} \mathrm{C}$ and pressures of up to $1 \mathrm{GPa}$ (Rütti, 2003). Growth of the second generation of staurolite is discussed below.

\subsection{Deformation phase D3}

Field observations

Third phase structures have developed obliquely to the trend of earlier structures and to the Penninic zone as a whole. In the region of Alpe Sponda, D3 folds strike N-S, but this strike progressively changes towards the north of the Simano Nappe into a NW-SE direction (Fig. 5). The presence of the D3 Campo Tencia synform, postulated by Grujic \& Mancktelow (1996), could be confirmed by the present study (Fig. 5). The eastern limb of the Campo Tencia synform is relatively steep in the Alpe Sponda region but becomes shallower toward the south (Pfiffner, 1999), where only the vergence of small-scale folds still suggests a larger-scale fold structure.

D3 produces a very characteristic undulation of the main foliation S2. D3 structures were not overprinted in the study area except in the very north, where all structures were steepened during the formation of the "Northern Steep Belt" of Milnes (1974a). D3 only rarely develops a penetrative foliation S3, which is exclusively observed in micaschists and mica-rich gneisses. Like S2, S3 dips toward $\mathrm{W}$ or SW but at a much steeper angle (ca. $60^{\circ}$ ).

Generally, D3 folding is variably developed throughout the Simano Nappe. The occurrence and geometry of D3 folds depends strongly on rock type and the fold style is often markedly disharmonic. Fold amplitudes change rapidly along the hinges of individual folds. With respect to D1 and D2 folds, D3 folds are characterized by a larger wavelength to amplitude 


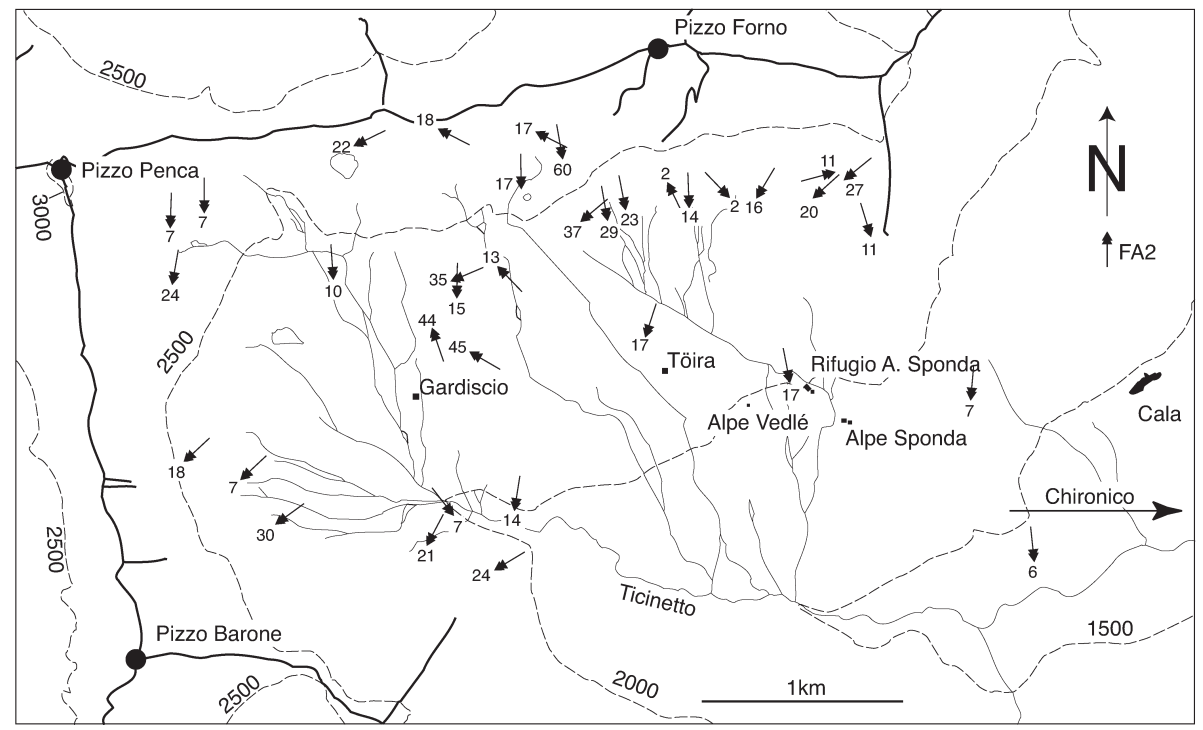

Fig. 7. Map of fold axes $\mathrm{FA}^{2}$ in the upper Val Chironico. The $\mathrm{FA}^{2}$ fold axes are often oblique to the $\mathrm{L}^{2}$ lineations in this region (compare with Fig. 6). This lack of parallelism reflects both the strong heterogeneity in development of the deformation phase $\mathrm{D}^{2}$ and the pre-structuring of the nappe prior to $\mathrm{D}^{2}$. ratio. This may in part be due to increased bending resistance during refolding (Grujic and Mancktelow, 1996). Banded gneisses and micaschists react mainly by layer-parallel thickening, with only slight undulatory folding of large wavelength and small amplitude.

\section{Microstructures}

The stable mineral assemblage of metapelites of the Simano Nappe during D3 is essentially the same as for D2 (garnet, kyanite, staurolite, biotite, muscovite, quartz and plagioclase), but it appears that in most samples staurolite grows preferentially during D3. In some cases, it grows across the main foliation, aligned in the direction of the newly formed foliation S3. Kyanite growing during D3 is less frequently observed. There is also new growth of biotite, as shown by the orientation of new grains oblique to the dominant foliation S2. Biotite belongs to the stable assemblage biotite, staurolite, plagioclase, garnet, muscovite and quartz. Garnet shows mainly resorption during this phase of deformation, with new staurolite produced as a result (Rütti, 2003). This new staurolite has euhedral outlines when it grows into mica-dominated portions of the main foliation. During D3, paragonite reacts to form plagioclase in Al-rich metapelites, with new grains of plagioclase growing during this phase. The alteration of biotite and garnet to chlorite is attributed to an even later stage, post-dating D3. Prevailing P-T conditions during D3 are estimated at $600-650^{\circ} \mathrm{C}$ and pressures of 0.6-0.8 GPa (Rütti, 2003).

\subsection{Brittle deformation}

Steeply dipping large-scale faults and more local fractures with small amounts of throw are observed in the entire Central Alps and cut across all nappe boundaries (e.g. Steck, 1968).
Fracture systems are clearly recognizable on aerial photographs and topographic maps, because they are often demarcated by deeply cut creeks (e.g. the west side of Valle Leventina). Most of the fracture systems strike E-W to ENE-WSW.

Flat-lying brittle faults are less common but may locally be more important than previously realized. Several characteristic features of this flat-lying brittle deformation can be well established in one specific outcrop above Faidal in Valle Leventina (SwissGrid coordinates 711825/136925, altitude $1000 \mathrm{~m}$ ). This outcrop is situated in the Leventina Gneisses, some 200 meters below the boundary with the Simano Nappe and within the mylonitic horizon marking the boundary to the Leventina Gneisses.

A $1 \mathrm{~cm}$ wide layer of ultracataclasite (dip direction/dip: $220^{\circ} / 5^{\circ}$ ) cuts across the entire outcrop. This layer is subparallel to the main foliation S2 (Fig. 8d). A thin section of this band (Fig. 8e) shows the cataclastic nature of the localized deformation, but without clear evidence of pseudotachylyte formation. In the field, this ultracataclasite is clearly associated with a brittle fault gouge (Fig. 8d). Pseudotachylytes do occur in Valle Leventina and were first described by Irouschek \& Huber (1982). According to Timar-Geng et al. (2004), the pseudotachylytes are distributed between Val Chironico and Val Cramosino and are consistently associated with the high strain zone at the boundary between the Simano and Leventina units. Kink folds deforming the dominant mylonitic foliation also overprint the ultracataclasite layer in this outcrop (Fig. 8f). The relative chronology (old to young) in this location is (1) mylonite, (2) ultracataclasite, (3) fault gouge, and (4) kink folds. The observations at this locality are important in that they establish that there has been a significant late brittle reactivation of the contact between the Simano Nappe and the Leventina Gneisses (see also TimarGeng et al., 2004). 

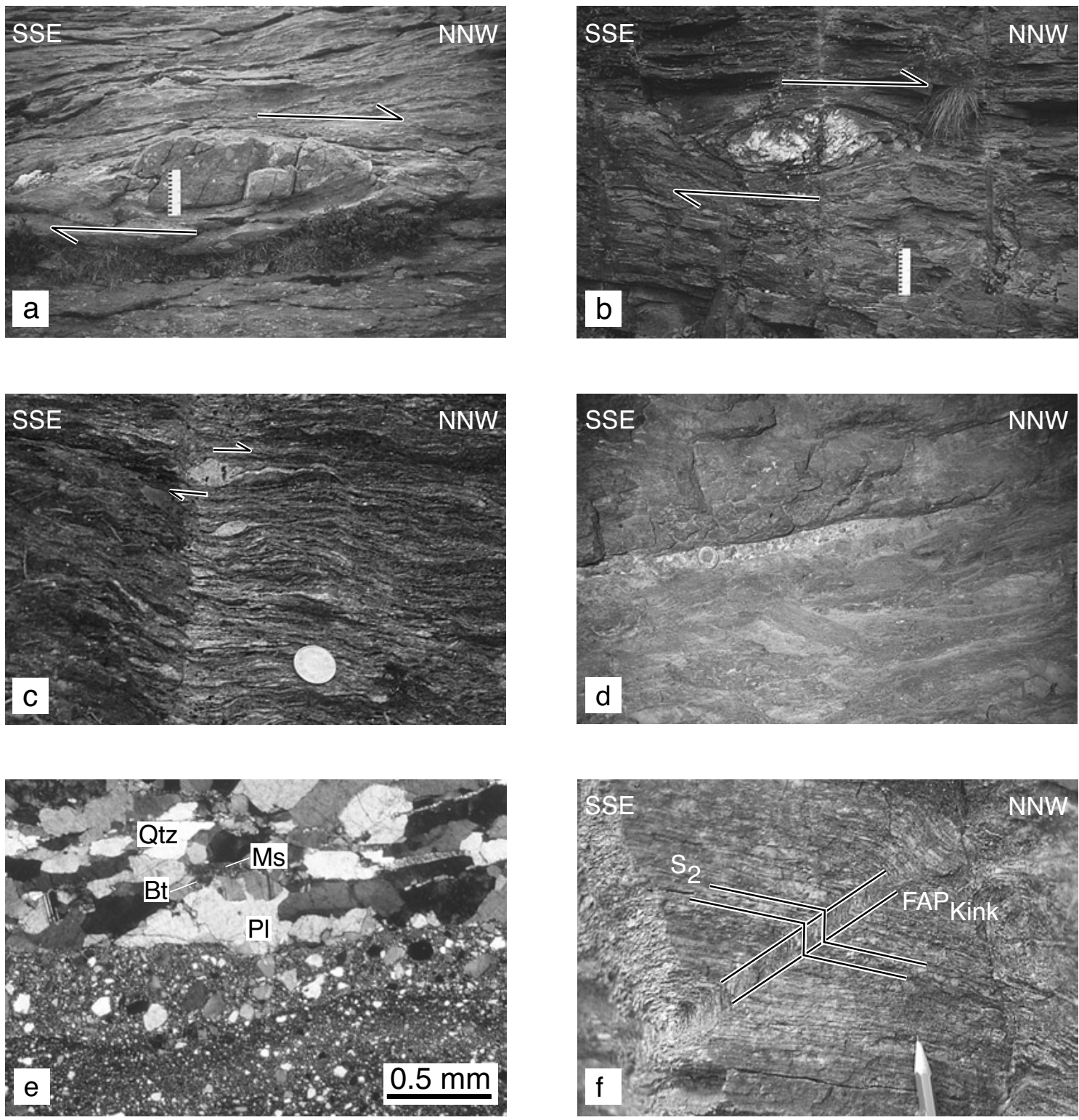

Fig. 8. Field photographs and microphotographs of ductile and brittle features observed in the Simano Nappe and the Leventina Gneisses. a) Boudinaged calcsilicate nodule in the region of Alpe Sponda showing NW-SE extension and a shear sense top-to-NW. Length of scale is $20 \mathrm{~cm}$ (Swiss Coordinates 702670/142060). b) Quartz nodule contained within the main foliation $\mathrm{S}^{2}$ near Faido (Swiss coordinates 705520/147010) showing a top-to-NW sense of shear. Length of scale is $20 \mathrm{~cm}$. c) Asymmetric feldspar clasts showing top-to-NW sense of shear at the same location as b). The diameter of the coin is $2 \mathrm{~cm}$ (Swiss Coordinates 705520/147010). d) Ultracataclasite horizon in the Leventina Gneisses (diameter of the coin is $1 \mathrm{~cm}$ ). A fault breccia is observed at the borders of the ultracataclasite. e) Microphotograph of the ultracataclasite pictured in d). f) Kinked D2 foliation in the Leventina Gneisses. The chronology from old to young is ultracataclasite - fault gouge - kink folds.

\section{The boundaries of the Simano Nappe}

\subsection{Simano Nappe - Leventina Gneisses boundary}

Field observations

Bossard (in Niggli et al., 1936) was the first to postulate that the Leventina Gneisses form an independent nappe. He presented many arguments in support of this proposal, ranging from the extent and size of the Leventina Gneisses to the difference in mineral composition of the Leventina Gneisses with respect to the Simano and Lucomagno units. Bossard described in detail the position of the proposed separator between the Leventina Gneisses and the Simano Nappe, based mainly on the occurrence of quartzites and quartz-rich rocks. Where these do not occur, amphibolites were taken as the equivalent of metamorphosed marly sediments and therefore to represent the boundary. The presence of strongly deformed 

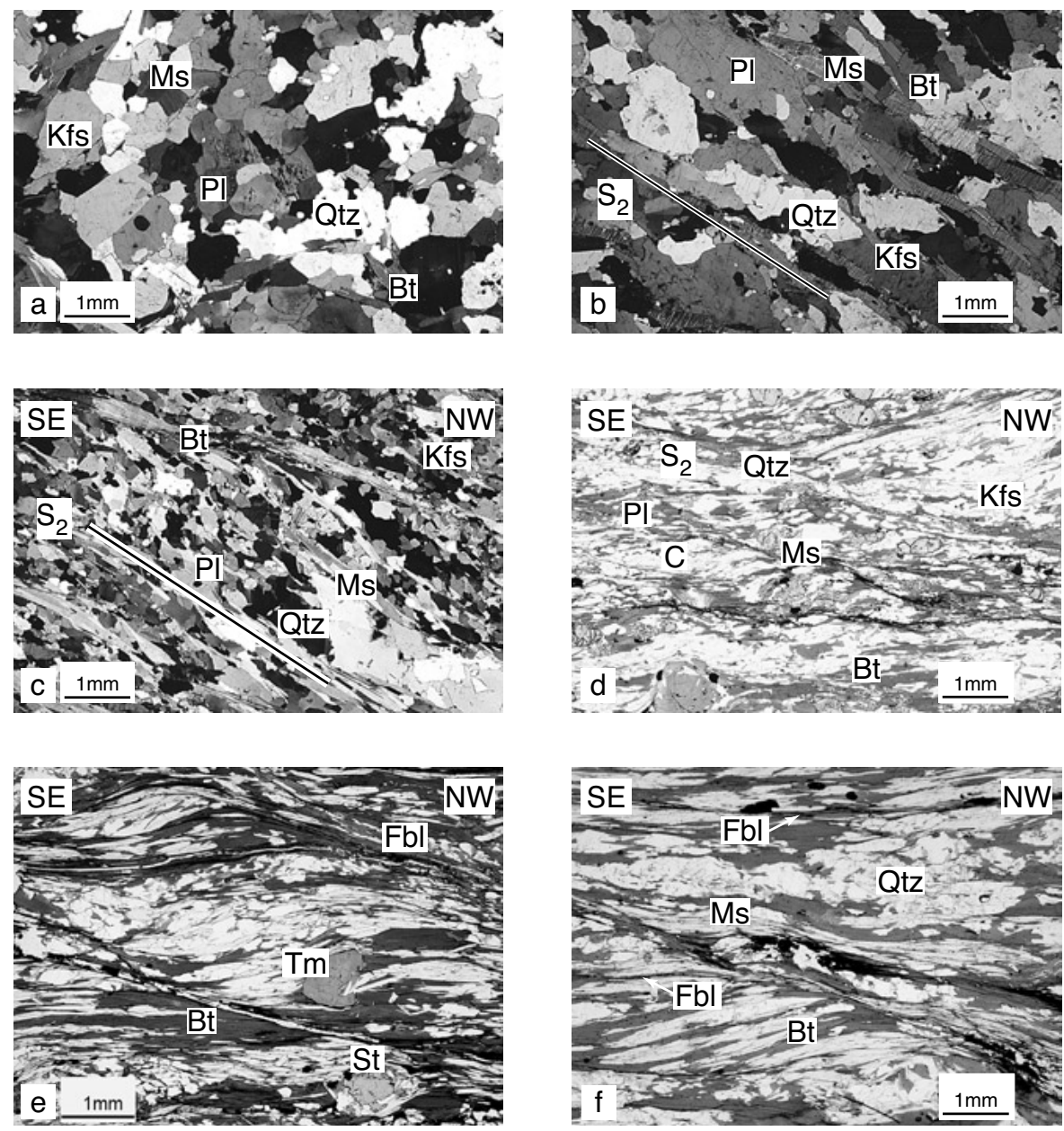

Fig. 9. Microphotographs of the increasing ductile deformation at the boundary between the Leventina Gneisses and the Simano Nappe. a) Little deformed metagranite of the Leventina Gneisses (Cresciano, Swiss coordinates 721180/125830). b) Leventina Gneisses showing a weak S2 foliation (quarry at Iragna, Swiss Coordinates 718200/129925). c) Penetrative S2 foliation developed in Leventina Gneisses (Val Cramosino, Swiss coordinates 710100/138275). d) Strongly deformed Leventina Gneiss from the Simano-Leventina boundary (W of Faido, Swiss coordinates 705520/147010). The shear bands give a top-to-NW sense of shear. e) Syn-D2 garnet and biotite in fibrolite-bearing metapelite of lower Val Chironico (Swiss coordinates 706200/141425). f) Fibrolite in the same rock as e), which has grown during the $\mathrm{D}^{2}$ shearing event with a top-to-NW sense of shear. rocks along this boundary was also already recognized by Bossard. He argued that in order to define tectonic limits, not only the position of Triassic and younger rocks has to be considered, but also the structure of the surrounding older rocks has to be taken into account. The detailed mapping of the Leventina Gneisses by Casasopra (1939) confirmed the presence of a strongly deformed horizon at the Simano-Leventina Gneisses boundary, as more recently again described by Merle et al. (1989) and Timar-Geng et al. (2004). Casasopra (1939) also considered the problematic nature of the quartzites as a nappe separator. He presented a modal estimation of such a "quartzite", which actually fits the modal composition of a granite (Casasopra, 1939; p. 591: quartz 37.6\%, K-feldspar $24.1 \%$, plagioclase $22.1 \%$, muscovite $15.0 \%$, biotite $1.0 \%$, accessory phases $0.25 \%$; region of Faido).

The mylonitic horizon between the Simano Nappe and the Leventina Gneisses occurs along the entire western side of Valle Leventina between Faido and Biasca and is present as far as the southern limit of the Leventina Gneisses according to Casasopra (1939). The horizon has a thickness varying between 50 and $200 \mathrm{~m}$. In some cases, a very leucocratic rock (quartz + feldspar + biotite + muscovite, i.e. a leucogranite) is associated with the mylonite. It is conceivable that some of these horizons were mapped as quartzites on the Preiswerk compilation map (Preiswerk et al., 1934). This would explain the granitic mode for a "Triassic quartzite" described by Casasopra (1939, p. 591). On the eastern side of the Valle Leventina, the situation is not as clear, mainly due to the lack of suitable outcrops. However, the existence of some of the quartzites mapped by Bossard could be confirmed.

\section{Microstructures}

The evolution of the microstructures in the Leventina Gneisses is well demonstrated in the microphotographs of Figure 9. A new foliation is already developed in the lowermost outcrops of the Leventina Gneisses. Some of the larger minerals are not fully reoriented into parallelism with this foliation, but all minerals are dynamically recrystallized (Fig. 9a). Myrmekites are frequently observed, which are a common precursor to recrystallization of feldspar (e.g. Simpson \& Wintsch, 1989). The Leventina Gneisses show a steadily increasing deformational overprint toward its upper boundary (Fig. 9b). Quartz shows subgrain formation, undulose extinc- 
tion and frequent grain size reduction along S2. Micas also show a decreasing grain size. Towards the top of Leventina Gneisses, the gneisses start to develop augen textures, with the augen formed by totally recrystallized feldspar clasts. The grain size of the matrix progressively decreases (Fig. 9c) into a strongly foliated, mylonitic zone within $200 \mathrm{~m}$ of the upper boundary (Fig. 9d). In this zone, shear bands are observed giving a sense of shear top-to-NW, which we assign to D2. The mylonitic overprint continues into the Simano Nappe, where the intensity of deformation again decreases. Different rock types (orthogneisses, paragneisses and schists) are all similarly affected. In the region of Chironico, Merle et al. (1989) described an outcrop (SwissGrid coordinates 706200/141450) where a top-to-W sense of shear was observed. These authors claim that at this locality shearing occurred under greenschist facies conditions. Samples from this outcrop show shear bands that are coeval with, or younger than, the main foliation S2. The shear sense is top-to-W to top-to-NW (S2 278/19; L2 $328 / 02$; shear bands $315 / 30$ ). The rock is a mylonitic metapelite with the mineral assemblage fibrolitic sillimanite + kyanite + staurolite + garnet + muscovite + biotite + quartz + feldspar + tourmaline. Fibrolite and tourmaline are only observed in shear bands, suggesting that they have grown during this shearing event (Fig. 9e, f). Garnet and staurolite are interpreted to have grown syn-D2 (Fig. 9e). Deformation took place under conditions of biotite stability, and chlorite is only present in minor amounts as a late alteration product of biotite and garnet.

The sillimanite-in isograd was originally mapped $20 \mathrm{~km}$ further to the south of Val Chironico (Niggli \& Niggli, 1965, Thompson, 1976). However, from their modelling of the isotherm and isobar-distribution of the Central Alps, Todd \& Engi (1997) claimed that the sillimanite-in isograd is in fact located in the region of the outcrops discussed here. Their results are supported by the earlier observations of Irouschek (1983), who reported fibrolite from lower Val Chironico. Because fibrolite occurs specifically in shear bands within the mylonitic zone between the Leventina Gneisses and the Simano Nappe, the fibrolite is interpreted to have grown synkinematically during D2.

\section{Discussion}

Many of the quartzite locations mapped by Bossard (Preiswerk et al., 1934; Niggli et al., 1936) could be confirmed, but the lack of associated Mesozoic metasediments does not allow the quartzites to be interpreted as a nappe separator with any certainty. In particular, some of the rocks previously mapped as quartzites have proven to be sheared leucogranites on more careful investigation. In map view (Fig. 2), there is a clear discordance between the Leventina Gneisses and the rocks of the overlying Simano Nappe. This, together with the lack of Mesozoic metasediments associated with the quartzites, suggests that the boundary between the Simano and Leventina units could represent a pre-Alpine intrusive contact. In this case, the Leventina Gneisses would represent a strongly deformed pluton of Hercynian age that was intruded into a portion of the southern European passive margin now corresponding to the Simano Nappe. However, it is clear that this contact has been strongly sheared during D2 and probably already during D1. Accordingly, the Leventina Gneisses have acted as a nappe during Alpine deformation, although still preserving remnants of their intrusive geometry.

This study, as well as the recent work of Timar-Geng et al. (2004), has found a dominant top-to-NW sense of shear in a zone marking the Simano-Leventina contact, which we attribute to D2 (Fig. 9). This is in contrast to the general top-toSE sense of shear attributed to D2 that has been previously reported from the region (Fig. 10; Baudin et al., 1993; Grujic \& Mancktelow, 1996; Pfiffner, 1999). This difference in shear sense may be due to the lower tectonostratigraphic position within the Alpine nappe pile, with top-to-NW thrusting at lower levels coeval with low-angle top-to-SE (normal?) faulting at higher levels during the D2 deformation phase.

\subsection{Simano Nappe - Maggia Nappe boundary}

\section{Field Observations}

For this study, the section of the contact between Fusio and Corona di Redorta has been investigated in detail. The boundary between the Simano and Maggia Nappes can be divided into three zones. Near the village of Fusio, the so-called Mogno synform (Fig. 11) of Alpine metasediments (Bündnerschiefer and Triassic dolomitic marbles) separates the paragneisses of the Campo Tencia body (Niggli et al., 1936) from those of the Maggia Nappe. In this zone, vergences of parasitic folds suggest that the Mogno synform evolved during D2, coeval with an adjacent antiform of identical trend but situated in the Simano Nappe (corresponding to the Larecc antiform of Keller, 1968; Figs. 11, 12, 13). The Larecc antiform forms a part of the regionally important Verzasca-Larecc-Ganna antiform (Fig. 14), which consists of several subordinate nappe-scale antiforms and synforms. On this scale, it corresponds to the frontal closure of the Simano Nappe (compare Maxelon \& Mancktelow, in press).

A second zone - the Pertusio zone - is usually interpreted as the southern continuation of the Mogno synform, although the uninterrupted connection cannot be proven (Fig. 11; Steck, 1998). Moreover, field work during this study could not unambiguously prove a synformal or antiformal position for this zone, as there is no clear change in D2 parasitic fold vergence to either side. The Pertusio zone separates mainly orthogneissic rocks (Ganna Gneiss GGa) to the east (and above) from orthogneisses again to the west (and below; Ruscada Gneiss GOR; Keller, 1968; Figs. 12, 13). The tectonic significance of the Pertusio zone is still equivocal. If a considerable amount of tectonic transport was associated with D2 (and specifically with the Mogno synform), this high strain zone could well be represented by the Pertusio zone further south (Figs. 12, 13). 


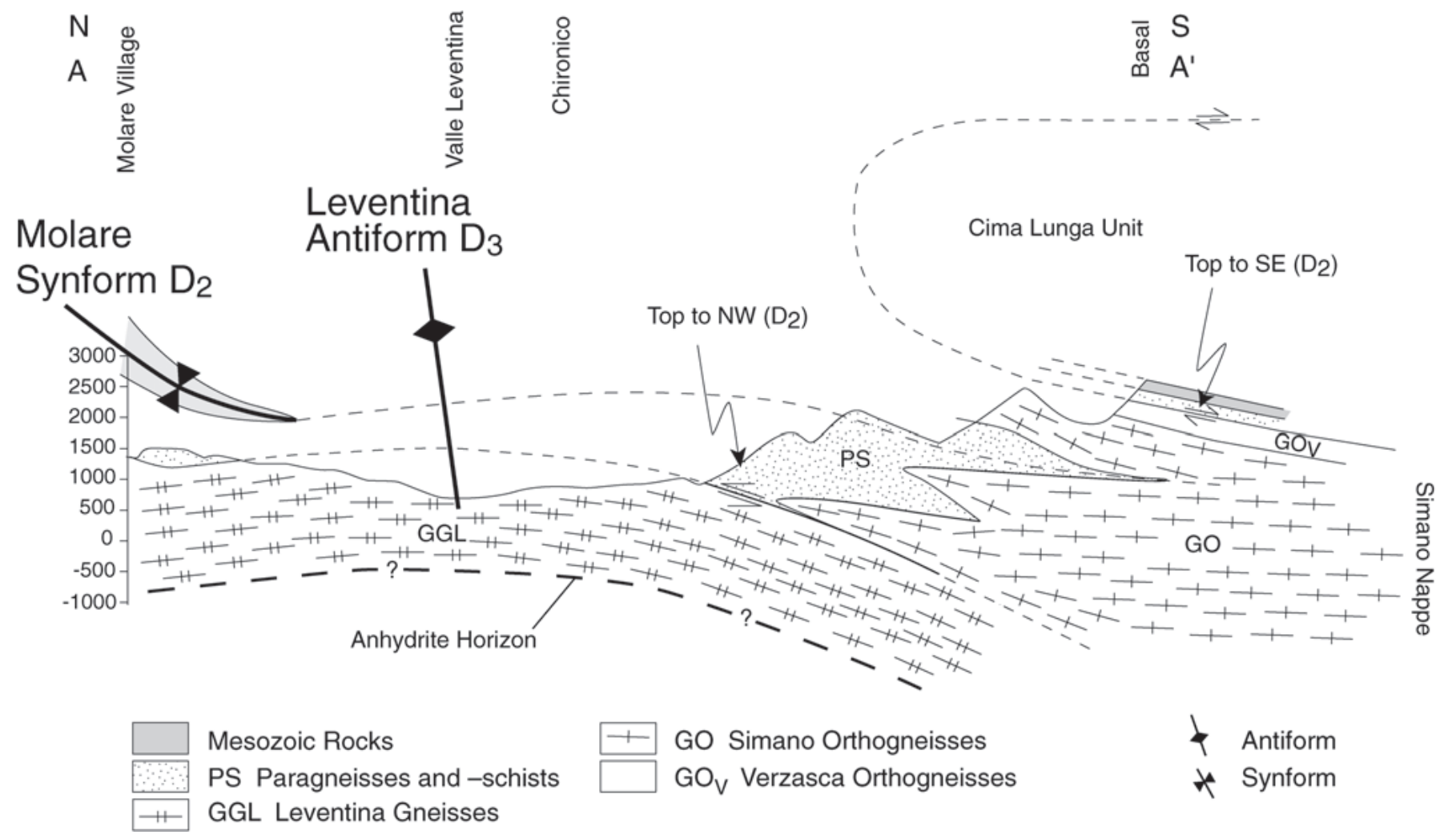

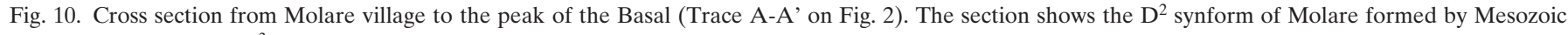

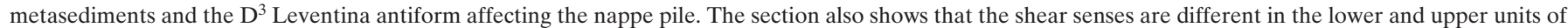
the Penninic zone. Whether the anhydrite horizon reported by Hiss (1975) actually represents a further nappe contact is uncertain.

Recognition of the often-cited antiform at the Corona di Redorta is mainly based on the rapid change in orientation of the main foliation S2 and the local pattern of outcrop lines of mapable units (Niggli et al., 1936; Merle et al., 1989; Steck, 1998; Fig. 13). We attribute this pattern to two different processes. Firstly, east of the Pertusio zone, a northwest-closing recumbent D2 antiform, the Larecc antiform of Keller (1968), is responsible for the pattern of outcrop lines (Fig. 12). A penetrative $\mathrm{S} 2$ foliation is developed parallel to the fold axial plane. We infer that the Larecc antiform is the antiformal counterpart of the (presumed) synformal structure corresponding to the Pertusio zone (Maxelon et al., 2002; Maxelon \& Mancktelow, in press). Subsequently this S2 foliation and the frontal part of the Larecc antiform were steepened to form the western limb of a broad D3 synformal structure - the Campo Tencia synform (Fig. 12). Since in this model the dominant foliation $\mathrm{S} 2$ was produced during formation of the D2 Mogno synform, its later modification in orientation cannot be the result of D2. Furthermore, the foliation orientation across the Corona di Redorta does not define an overturned fold, as has been repeatedly postulated (Niggli et al., 1936; Steck, 1998), but rather shows a simple steady steepening to the west (Grujic \& Mancktelow, 1996; Figs. 12, 13). Thus, the antiform at the Corona di Redorta is in fact a composite structure, consisting of a tight D2 antiform (the Larecc antiform), responsible for the outcrop pattern and a broad D3 synform (the Campo Tencia synform), causing the rapid steepening of the pre-existing S2 foliation on its western limb (Figs. 12, 13).

To the south, in the third zone, the Pertusio zone ends in a series of juxtaposed slices of para- and orthogneisses. Still further south, these gradually merge into more homogeneous gneiss bodies. A high strain zone or other structure possibly associated with a nappe contact is no longer evident.

\section{Discussion}

In the study area, the Maggia Nappe is generally situated tectonostratigraphically below the Simano Nappe. Moreover, these two units have a close structural relationship, because in the northern area they clearly represent alternate limbs of a synform-antiform pair, the Mogno synform and the Larecc antiform, or more generally the Verzasca-Larecc-Ganna antiform. As a consequence, the assignment of the Maggia Nappe to the Briançonnais paleogeographic domain (Froitzheim et al. 1996) is not justified.

We interpret the Maggia Steep Zone as the steepened western limb of the D3 Campo Tencia synform. The profile through Corona di Redorta (Fig. 12) shows the trend of the main folia- 


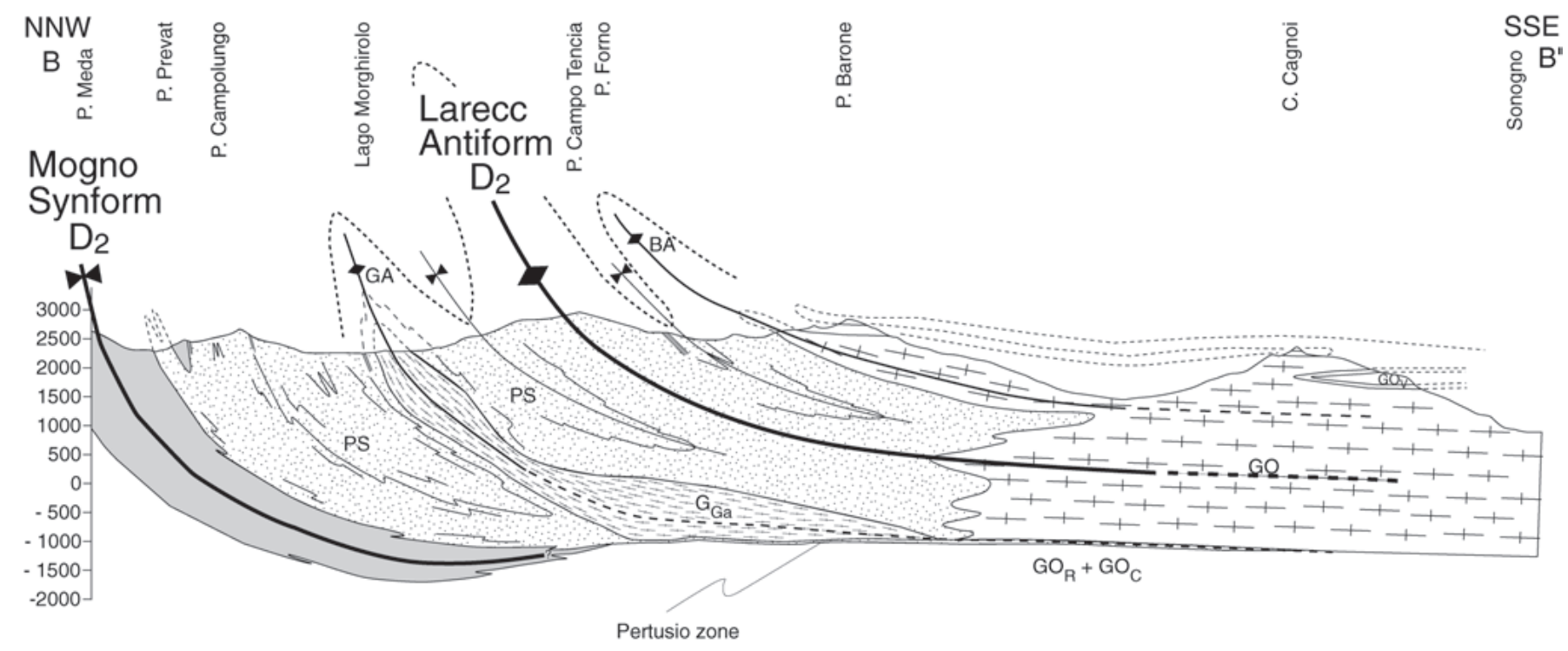

Mesozoic Rocks
PS Paragneisses and schists
$\quad \mathrm{G}_{\mathrm{Ga}}$ Ganna Gneiss

\begin{tabular}{l}
+1 GO Simano Orthogneisses \\
\hline$\square \mathrm{GO}_{\mathrm{V}}$ Verzasca Orthogneisses \\
$\mathrm{GO}_{\mathrm{R}}$ Ruscada Orthogneisses \\
$\mathrm{GO}_{\mathrm{C}}$ Cocco Orthogneisses
\end{tabular}

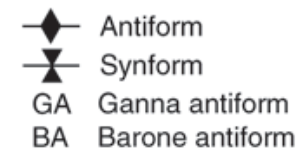

Fig. 11. Cross section from Pizzo Meda to Sonogno showing the internal structure of the metasediments in the frontal part of the Simano Nappe (Trace B-B' on Fig. 2). The Larecc antiform corresponds to a large-scale $D^{2}$ antiform, together with the smaller parasitic Ganna and Barone antiforms (GA, BA). The internal structure of the metasediments in the frontal Simano Nappe was deduced by tracing a garnet-rich metapelite.

tion S2 steepened by D3. There is no field evidence for the existence of a D3 synform within the Maggia Nappe followed by a D3 antiform in the east, as postulated by Merle et al. (1989) and Steck (1998). Based on D2 fold vergences, we interpret the Larecc antiform as a northwest closing D2 antiform, forming a part of the regional Verzasca-Larecc-Ganna composite antiform and lying within the western steep limb of the D3 Campo Tencia synform (Fig. 11, 12, 13). We also infer another D2 antiform adjacent to the Pertusio zone, as indicated by D2 fold vergences, which again forms part of the Verzasca-Larecc-Ganna antiform.

\section{Summary}

The axial traces of the principal D2 and D3 folds are shown on the map of Fig. 14, based on measurements conducted during this study and data from the literature (Keller, 1968; Berchtold, 1990; Hohl, 1990; Rüffer, 1990; Stoll, 1990; Grujic \& Mancktelow, 1996; Steck, 1998; Gunzenreiner, 1998; Albisetti, 1999; Maxelon \& Mancktelow, in press). The most prominent second phase fold is the Mogno synform, which can be traced into the Mesozoic cover in the northern part of the Central Alps and, in our interpretation, is connected over the Valle Leventina with the Molare synform to the east (Fig. 14). Further east, this synformal structure may continue into the Soja Zone. The Mogno synform can be traced further to the west and connected with the Pertusio zone, which can itself be traced to the region of Monte Zucchero before it wedges out (Fig. 14). The next major antiform above the Mogno synform is situated within the Simano Nappe and corresponds to the frontal D2 closure of the nappe. It is a composite structure consisting of a series of regional-scale parasitic syn- and antiforms. In this M-fold region, the interference between D1 and D2 structures can still be observed (e.g. Fig. 3a). From Pizzo Prévat to Lago Morghirolo, the dominant garnet-rich metapelites describe a succession of syn- and antiforms (Fig. 11), of which the Ganna antiform and the Prévat synform (Grujic \& Mancktelow, 1996; Steck, 1998) are two major examples. These large-scale parasitic M-folds combine to form the Verzasca-Larecc-Ganna composite antiform (Fig. 14), representing the frontal region of the Simano Nappe. In the metasediments south of Lago Morghirolo, the garnet-rich metapelites and associated parasitic M-folds have only been observed in the structurally higher levels of the Simano Nappe along the Pizzo Forno - Pizzo Penca ridge (Fig. 11).

The deformation phase D2 produced the present day recumbent fold pattern and dominant foliation throughout most of the Central Alps (e.g. Ayrton and Ramsay, 1974; Simpson, 1982; Baudin et al., 1993; Grond et al., 1995; Grujic \& Mancktelow, 1996; Pfiffner, 1999; Rütti, 2001; Nagel et al., 2002). However, regional, broader and more upright D3 structures 


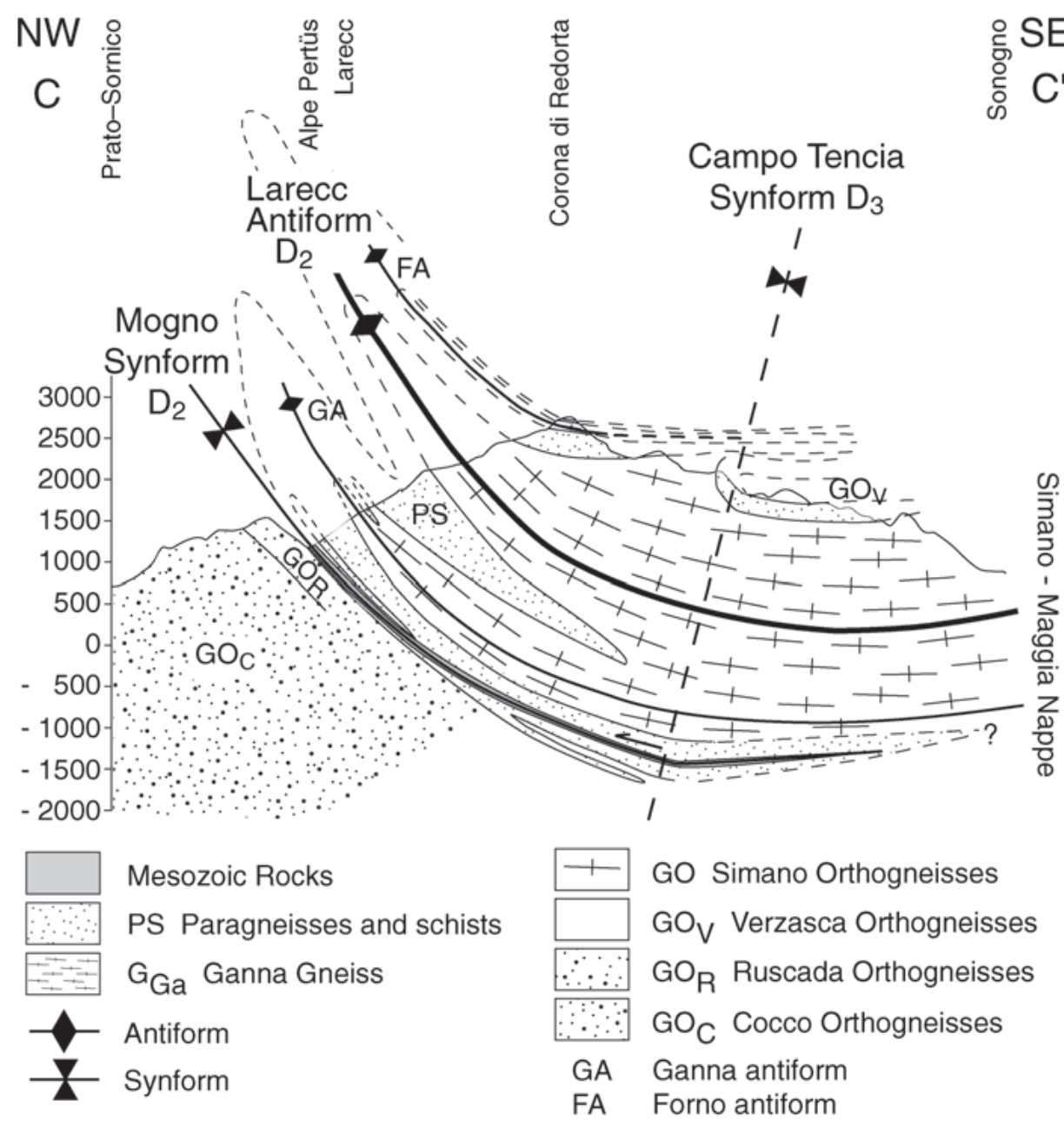

Fig. 12. Cross section from Prato-Sornico to Sonogno (Trace C-C' on Fig. 2). The Pertusio zone is on the lower limb of a D2 synform. This implies that the orthogneisses ( $\mathrm{GGa}, \mathrm{GO}$ and $\mathrm{GO}_{\mathrm{V}}$ ) of the Simano nappe are directly correlated with the orthogneiss bodies of the Maggia Nappe $\left(\mathrm{GO}_{\mathrm{R}}\right.$ and $\left.\mathrm{GO}_{\mathrm{C}}\right)$, i.e. they represent the same tectonostratigraphic unit. trending oblique to the orogen are very important for the overall foliation and nappe outcrop pattern of the Central Alps. In the study area, three large structures are observed (Fig. 14), namely the Leventina antiform, the Campo Tencia synform and the Maggia Steep Zone:

(1) The Leventina antiform corresponds to the Ticino culmination within the Lepontine Dome.

(2) The Campo Tencia synform is equivalent to the depression between the Ticino culmination and the Toce (or Simplon) culmination to the west (e.g. Merle et al., 1989).

(3) The asymmetric shape of the Campo Tencia synform involves a steep to subvertical western limb, with a monoclinal geometry relative to the adjacent western Toce (or Simplon) culmination. This steep monoclinal limb forms the Maggia Steep Zone oblique to the trend of the orogen and separating the two domal culminations.

Effects of later deformation phases are rare in the study area. Although the general steepening of the dominant foliation in the northernmost portions of the Simano Nappe is caused by the Chiéra Synform (and therefore ascribed to D4), no mesoscale structures of D4 origin were found in the study area. Younger structures (e.g. the D5 reclined, kinky folds of Grujic \& Mancktelow, 1996) were also not observed. Even younger steep brittle faults are most likely related to the exhumation of the Central Alps in the last 10-20 Ma (Steck, 1968; Purdy \& Stalder, 1973; Hurford, 1986). According to Timar-Geng et al. (2004), the flat-lying brittle reactivation of the Simano-Leventina Gneisses contact has a regional top-to-WNW shear sense. They propose that it may also relate to the same period of exhumation in the Alps, as marked by the Neogene Simplon and Brenner normal faults (e.g. Grasemann \& Mancktelow, 1993; Fügenschuh et al., 1997).

\section{Conclusions}

The study area is characterised by three clearly distinguishable Alpine deformation phases (D1, D2, D3). D1 developed under metamorphic conditions of ca. $1 \mathrm{GPa}$ and $500^{\circ} \mathrm{C}$, i.e. in mid- 


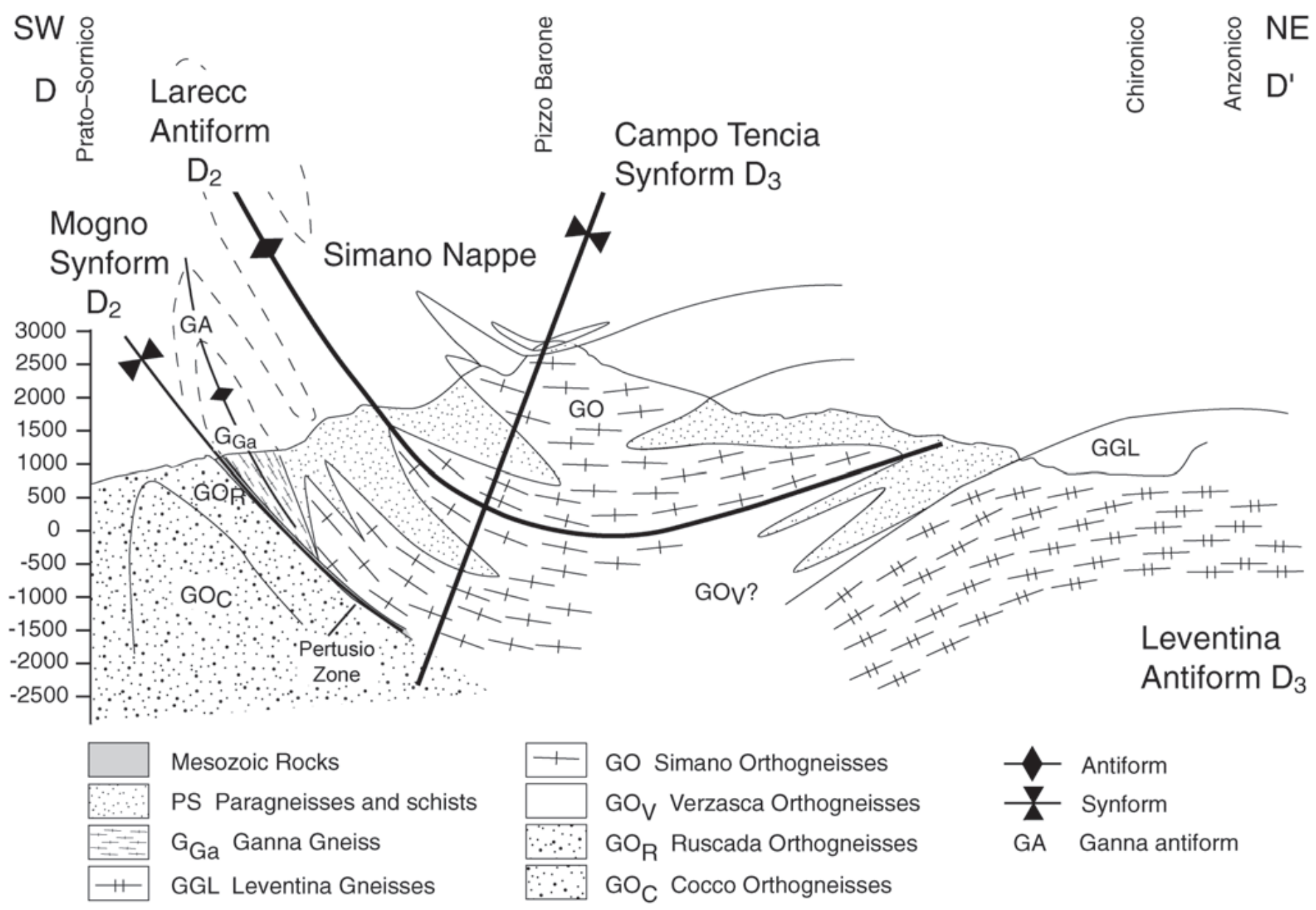

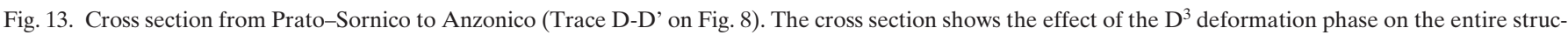
ture. During this phase the Campo Tencia synform as well as the Leventina antiform were generated. The steepening of the Larecc Antiform is due to this deformation phase.

crustal levels. It entailed the formation of kilometre-scale, recumbent, north-closing anticlinal folds, called nappes (the Alpine nappe-stacking event). These nappes were intensely refolded on the same scale and with identical style during D2 (Alpine isoclinal post-nappe folding). Subsequently, the whole tectonostratigraphy has been warped into wavy to open folds on all scales during D3. Peak metamorphic conditions occurred between D2 and D3 with pressures of 0.7-0.8 GPa and up to $650^{\circ} \mathrm{C}$.

As a consequence of this particular deformation history, lithological units separated only by D2-synforms belonged to the same tectonostratigraphic level subsequent to D1. Therefore, they should not be interpreted as different nappes (i.e. different tectonostratigraphic levels, as established during the D1 nappe-stacking). This principle can be directly applied to the relationship between the Maggia and Simano units: they are separated only by the D2 Mogno Synform and therefore belong to the same major nappe unit. The Leventina Gneisses are separated from the Simano rocks by an originally intrusive contact that has been strongly reactivated during both D1 and D2. Therefore, it is taken to represent a true nappe contact, even though it locally still retains some original intrusive relationships and has also been strongly reactivated during D2.

If the Maggia unit is simply the continuation of the Simano unit around the D2 Mogno synform, then it cannot be assigned to the Briançonnais paleogeographic unit. All tectonic units of the study area belong to the passive continental margin of Europe prior to the onset of the Alpine collisional orogenesis.

\section{Acknowledgements}

This contribution is part of the Ph. D thesis of RR and funding from ETH Zürich (Grant No. 0-20738-99) is acknowledged. RR is grateful to Alan Thompson and Jamie Connolly for their support and advice throughout his thesis. Lively discussions with T. Burri and A. Berger from the University of Berne are gratefully acknowledged. Comments from Stefan Schmid and an anonymous reviewer helped to improve the paper. Andreas Baumeler is thanked for the help with the figures. 


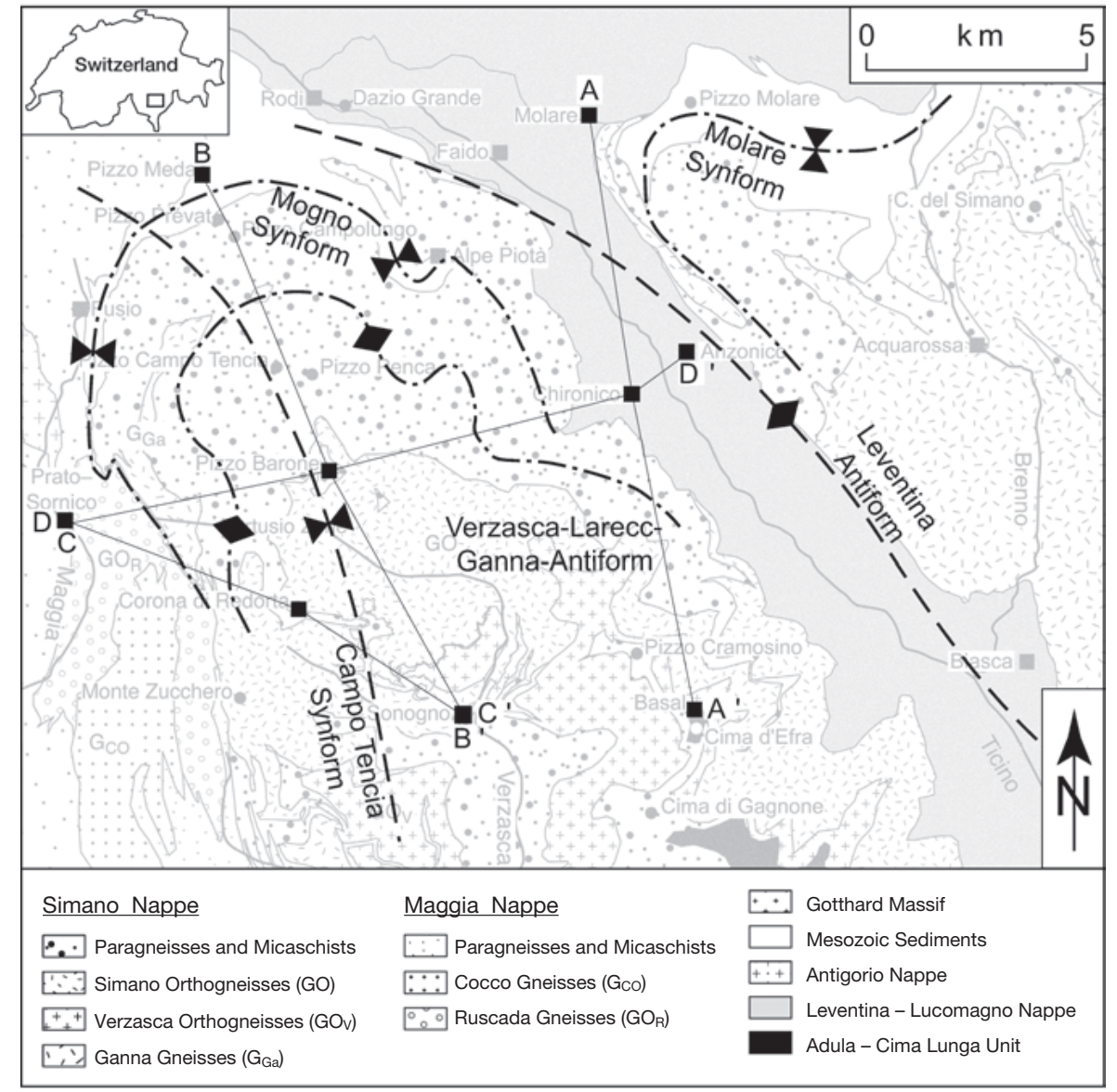

Fig. 14. Map of the axial trace of major $\mathrm{D}^{2}$ and $\mathrm{D}^{3}$ syn- and antiforms in the study area. The locations of the sections given in Figs. 10, 11, 12 and 13 are also indicated.

\section{REFERENCES}

Albisetri, D. 1999: Petrografia e geologia strutturale delle falde Maggia e Campo Tencia/Simano nella regione del Campolungo. Unpublished Diploma Thesis, ETH Zürich, 122 pp.

Allègre, C.J., Albarède, F., Grünenfelder, M. \& Köppel, V. 1974: ${ }^{238} \mathrm{U} /{ }^{206} \mathrm{~Pb}-{ }^{235} \mathrm{U}^{207} \mathrm{~Pb}-{ }^{232} \mathrm{Th} /{ }^{208} \mathrm{~Pb}$ zircon geochronology in Alpine and non-Alpine environment. Contrib. Mineral. Petrol. 43, 163-194.

Argand, E. 1911: Les nappes de recouvrement des Alpes Penniques et leurs prolongements structuraux. Beitr. Geol. Karte Schweiz. N.F. 31. Schweizerische Geologische Kommission, Bern, 109 pp.

Ayrton, S.N. \& RAMSAY, J.G. 1974: Tectonic and metamorphic events in the Alps. Schweiz. Mineral. Petrogr. Mitt. 54, 609-639.

Baudin, T., Marquer, D. \& Persoz, F. 1993: Basement-cover relationships in the Tambo nappe (Central Alps, Switzerland): geometry, structure and kinematics. J. Struct. Geol. 15, 543-553.

Baumgartner, L. \& Löw, S. 1983: Deformation und Metamorphose der Adula-Decke südwestlich San Bernardino. Schweiz. Mineral. Petrogr. Mitt. 63, 215-232.

Berchtold, P. 1990. Petrographie und Strukturgeologie um Fusio, Teil 4. Unpublished Diploma Thesis, ETH Zürich, 109 pp.

BiAnCONI, F. 1971: Geologia e petrografia della regione del Campolungo. Beitr. Geol. Karte Schweiz. N.F. 142. Schweizerische Geologische Kommission, Bern, 238 pp.

Buchmann, H. 1953: Geologie und Petrographie des oberen Maggia-Tales zwischen Fusio und Broglio im NW-Tessin. Ph.D. Thesis, Universität Basel, 117 pp.

CASASOPRA, S.F. 1939: Studio petrografico dello Gneiss granitico Leventina (Valle Riviera e Valle Leventina, Canton Ticino). Schweiz. Mineral. Petrogr. Mitt. 19, 449-708.
- 1948a: Brevi cenni sulla genesi del granito gneissico Leventina (Riviera e Leventina, Ct. Ticino). Schweiz. Mineral. Petrogr. Mitt. 28, 127-139.

- 1948b: Note sulla petrochimica dello gneiss-granito Leventina (Riviera e Leventina, Ct. Ticino). Schweiz. Mineral. Petrogr. Mitt. 28, 717-756.

- 1953: Quarziti e vene filoniane sul fronte settentrionale dello gneiss-granito Leventina (GGL). Schweiz. Mineral. Petrogr. Mitt. 33, 511-512.

Codoni, A. 1981: Geologia e petrografia della regione del Pizzo di Claro. Ph.D. Thesis, ETH Zürich, 179 pp.

EngI, M., TodD, C.S. \& SchmatZ, D.R. 1995: Tertiary metamorphic conditions in the eastern Lepontine Alps. Schweiz. Mineral. Petrogr. Mitt. 75, 347-369.

EtTer, U. 1992: Die Chiéra-Synform. Bull. Ver. schweiz. Petroleum-Geol. u. Ing. 59, 93-99.

Frey, M., Hunziker, J.C., Frank, W., Bocquet, J., Piaz, G.V.D., Jäger, E. \& NiggLI, E. 1974: Alpine metamorphism of the Alps. A review. Schweiz. Mineral. Petrogr. Mitt. 54, 247-290.

- JÄGER, E. \& NIGGLI, E. 1976: Gesteinsmetamorphose im Bereich der Geotraverse Basel-Chiasso. Schweiz. Mineral. Petrogr. Mitt. 56, 649-659.

Froitzheim, N., Schmid, S.M. \& Frey, M. 1996: Mesozoic paleogeography and the timing of eclogite-facies metamorphism in the Alps: a working hypothesis. Eclogae geol. Helv. 89, 81-110.

Fügenschun, B., SeWard, D. \& ManckTelow, N.S. 1997: Exhumation in a convergent orogen: the western Tauern window. Terra Nova 9, 213-217.

Gerlach, H. 1869: Die Penninischen Alpen, Beiträge zur Geologie der Schweiz. Denkschr. Schweiz. natf. Ges. 23. 132 pp.

Giger, R. 2000: Geologie und Petrographie der Cima Lunga-Einheit im Val Pincascia, Ticino. Teil II: Metabasika. Unpublished Diploma Thesis, ETH Zürich, 153 pp.

Grasemann, B. \& Mancktelow, N.S. 1993: Two-dimensional thermal modelling of normal faulting: the Simplon Fault Zone, Central Alps, Switzerland. Tectonophysics 225, 155-165. 
Grond, R., WAHL, F. \& Pfiffner, M. 1995: Mehrphasige alpine Deformation und Metamorphose in der nördlichen Cima-Lunga-Einheit, Zentralalpen (Schweiz). Schweiz. Mineral. Petrogr. Mitt. 75, 371-386.

GRUJIC, D. \& MANCKTELOW, N.S. 1996: Structure of the northern Maggia and Lebendun nappes, Central Alps, Switzerland. Eclogae geol. Helv. 89, 461-504.

GüntherT, A. 1954 Beiträge zur Petrographie und Geologie des Maggia-Lappens (NW-Tessin). Ph.D. Thesis, Universität Basel, 159 pp.

- Stern, W.B. \& Schwander, H. 1996: The polycyclic evolution of the Penninic Maggia nappe, Central Alps: a summary report. Schweiz. Mineral. Petrogr. Mitt. 76, 1-22.

GunZenReiner, S. 1998: Petrographie und Strukturgeologie zwischen Maggia- und Campo Tencia-Decke im Gebiet des Passo Campolungo. Unpublished Diploma Thesis, ETH Zürich, 74 pp.

HALL, W.D.M., 1972: The structural geology and metamorphic history of the lower Pennine Nappes, Valle di Bosco, Ticino, Switzerland. PhD Thesis, Imperial College, London, $220 \mathrm{pp}$.

Heıм, A. 1919-1922: Geologie der Schweiz (in 2 Vol.). Tauchnitz, Leipzig. 704 resp. 1018 pp.

HEINRICH, C.A. 1986: Eclogite facies regional metamorphism of hydrous mafic rocks in the Central Alpine Adula Nappe. J. Petrol. 27, 123-154.

Hezner, L. 1909: Der Peridotit von Loderio. Viertelj. Naturforsch. Ges. Zürich, 54, 244-260.

Higgins, A.K. 1964: The structural and metamorphic geology of the area between Nufenenpass and Basódino, Tessin, S. Switzerland. PhD Thesis, Imperial College, London.

Hiss, B.M. 1975: Petrographische Untersuchungen der SBB-Sondierbohrung Biaschina (TI). Schweiz. Mineral. Petrogr. Mitt., 55, 201-215.

HoHL, A.-F. 1990: Petrografia e Geologia strutturale nella regione di Fusio, Valle Maggia (Ti), I parte. Unpublished Diploma Thesis, ETH Zürich, 84 pp.

Huber, M., Ramsay, J.G. \& Simpson, C. 1980: Deformation in the Maggia and Antigorio nappes, Lepontine Alps. Eclogae geol. Helv. 73, 593-606.

Huber, R.K. \& Marquer, D. 1998: The tectonometamorphic history of the peridotitic Chiavenna unit from Mesozoic to Tertiary tectonics: a restoration controlled by melt polarity indicators (Eastern Swiss Alps). Tectonophysics 296, 205-223.

HURFORD, A. J. 1986: Cooling and uplift patterns in the Lepontine Alps south central Switzerland and an age of vertical movement on the Insubric fault line. Contrib. Mineral. Petrol. 92, 413-427.

IrouscheK, A. \& Huber, M. 1982: Pseudotachylite zones in the Leventina Gneiss (Lepontine Alps, Ticino, Switzerland). Schweiz. Mineral. Petrogr. Mitt. 62, 313-325.

- 1983: Mineralogie und Petrographie von Metapeliten der Simano-Decke mit besonderer Berücksichtigung cordieritführender Gesteine zwischen Alpe Sponda und Biasca. Ph.D. Thesis, Universität Basel, 205 pp.

Jenny, H., Frischknecht, G. \& Kopp, J. 1923: Geologie der Adula. Beitr. Geol. Karte Schweiz. N.F. 51. Schweizerische Geologische Kommission, Bern, 123 pp.

KelLeR, F. 1968: Mineralparagenesen und Geologie der Campo Tencia-Pizzo Forno-Gebirgsgruppe. Beitr. Geol. Karte Schweiz. N.F. 135. Schweizerische Geologische Kommission, Bern, 71 pp.

- Wenk, E., Bianconi, F. \& Hasler, P. 1980: Geologischer Atlas der Schweiz 1:25000: 1272 P. Campo Tencia. Schweizerische Geologische Kommission. Bern.

KLAPER, E.M. 1982: Deformation und Metamorphose in der nördlichen Maggiazone. Schweiz. Mineral. Petrogr. Mitt. 62, 47-76.

KÖPPEL, V. \& GRÜNENFELDER, M. 1975: Concordant U-Pb ages of monazite and xenotime from the Central Alps and the timing of the high temperature Alpine metamorphism, a preliminairy report. Schweiz. Mineral. Petrogr. Mitt. 55, 129-132.

- Günthert, A. \& Grünenfelder, M. 1980: Patterns of U-Pb zircon and monazite ages in polymetamorphic units of the Swiss Central Alps. Schweiz. Mineral. Petrogr. Mitt. 61, 97-119.

- 1993: The Lepontine area, a geochronological summary. In: Pre-Mesozoic Geology in the Alps (eds von Raumer, J.F. \& Neubauer, F.) SpringerVerlag, Berlin, 345-348.
KÜNDIG, E. 1936: Tektonischer Überblick über die gesamten Tessiner Alpen. In: Geologische Beschreibung der Tessiner Alpen zwischen Maggia- und Bleniotal (ed. Niggli, P.) Beitr. Geol. Karte Schweiz. N. F. 71. Schweizerische Geologische Kommission, Bern. 101-132.

Löw, S. 1987: Die tektono-metamorphische Entwicklung der nördlichen Adula-Decke (Zentralalpen, Schweiz). Beitr. Geol. Karte Schweiz. N.F. 161. Schweizerische Geologische Kommission, Bern. 84 pp.

MANCKTELOW, N.S. 1994: Geometry, kinematics and timing of deformation in the Central Alps. Abstract Volume, 2nd Workshop on Alpine Geology, 36-38.

MARqueR, D. 1991: Structures et cinématique des déformations alpines dans le granite de Truzzo (Nappe de Tambo: Alpes Centrales Suisses). Eclogae geol. Helv. 84, 107-123.

MAXelon, M. \& MANCKTElow, N.S. IN PRESS: Three-dimensional geometry and tectonostratigraphy of the Pennine Zone, Central Alps, Switzerland and Northern Italy. Earth Science Reviews.

Maxelon, M., Mancktelow, N.S., Rütti, R. \& Renard, P. 2002: Regional correlation of polyphase fold structures in the Maggia Region, Central Alps - An approach based on 3D geometric modelling. Erlanger Geol. Abh. Sonderband 3, 63.

Merle, O. \& Le Gal, P. 1988: Post-amphibolitic westward thrusting and fold vergence in the Ticino domain. Eclogae geol. Helv. 81, 215-226.

Merle, O., Cobbold, P.R. \& Schmid, S.M. 1989: Tertiary kinematics in the Lepontine dome. In: Alpine Tectonics (eds Coward, M.P., Dietrich, D. \& Park, R.G.). Geol. Soc. Spec. Publ. Nr. 45, 113-134.

Meyre, C. \& Puschnig, A.R. 1993: High-pressure metamorphism and deformation at Trescolmen, Adula nappe, Central Alps. Schweiz. Mineral. Petrogr. Mitt. 73, 277-283.

Milnes, A.G. 1974a: Post-nappe folding in the western Lepontine Alps. Eclogae geol. Helv. 67, 333-348.

- 1974b: Structure of the Pennine zone (Central Alps): A new working hypothesis. Geol. Soc. Amer. Bull. 85, 1727-1732.

- 1976: Strukturelle Probleme im Bereich der Schweizer Geotraverse - das Lukmanier-Massiv. Schweiz. Mineral. Petrogr. Mitt. 56, 615-618.

Nagel, T., de Capitani, C., Frey, M., Froitzheim, N., Stünitz, H. \& SCHMID, S.M. 2002: Structural and metamorphic evolution during rapid exhumation in the Lepontine dome (southern Simano and Adula nappes, Central Alps, Switzerland). Eclogae geol. Helv. 95, 301-321.

Niggli, P., Preiswerk, H., Grütter, O., Bossard, L. \& Kündig, E. 1936 Geologische Beschreibung der Tessiner Alpen zwischen Maggia- und Bleniotal. Beitr. Geol. Karte Schweiz. N.F. 71. Schweizerische Geologische Kommission, Bern, 190 pp.

NigGLI, E. \& NigGLI, C.R. 1965: Karten der Verbreitung einiger Mineralien der alpidischen Metamorphose in den Schweizer Alpen (Stilpnomelan, Alkali-Amphibol, Chloritoid, Staurolith, Disthen, Sillimanit). Eclogae geol. Helv. 58, 335-368.

PARTZSCH, J.H. 1998: The tectono-metamorphic evolution of the middle Adula nappe, Central Alps, Switzerland. Ph.D. Thesis, Universität Basel, $142 \mathrm{pp}$.

Pfiffner, O.A., Frei, W., Valasek, P., Stäuble, M., Levato, L., Dubois, L., SCHMid, S.M. \& SMithson, S.B. 1990: Crustal shortening in the Alpine orogen: Results from deep seismic reflection profiling in the Eastern Swiss Alps, Line NFP 20-East. Tectonics 9, 1327-1355.

PfIFFNER, M. 1999: Genese der hochdruckmetamorphen ozeanischen Abfolge der Cima Lunga Einheit (Zentralalpen). Ph.D. Thesis, ETH Zürich, 248 pp.

Preiswerk, H. 1918a: Geologische Beschreibung der Lepontinischen Alpen. Beitr. Geol. Karte Schweiz. N.F. 26. Schweizerische Geologische Kommission, Bern, 80 pp.

1918b: Geologische Spezialkarte Nr. 81: Geologische Karte des oberen Tessins und des Maggiatales 1:50000. Schweizerische Geologische Kommission, Bern.

- 1921: Die zwei Deckenkulmination Tosa-Tessin und die Tessiner Querfalte. Eclogae geol. Helv. 16, 485-496.

- Bossard, L., Grütter, O., Niggli, P., Kündig, E. \& Ambühl, E. 1934 Geologische Spezialkarte Nr. 116: Geologische Karte der Tessineralpen zwischen Maggia- und Blenio-Tal 1:50000. Schweizerische Geologische Kommission, Bern. 
Purdy, J.W. \& Stalder, H.A. 1973: K-Ar ages of fissure minerals from the Swiss Alps. Schweiz. Mineral. Petrogr. Mitt. 53, 79-98.

RÜFFER, M. 1990: Petrographie und Strukturgeologie um Fusio, Teil 3. Unpublished Diploma Thesis, ETH Zurich, 89 pp.

RÜTTI, R. 2001: Tectono-metamorphic evolution of the Simano-Adula nappe boundary, Central Alps, Switzerland. Schweiz. Mineral. Petrogr. Mitt. 81, 115-129.

RÜTTI, R. 2003: The tectono-metamorphic evolution of the northwestern Simano Nappe (Central Alps, Switzerland). Ph.D. Thesis, ETH Zurich, 112 pp.

SASSI, F.P. 1972: The petrological and geological significance of the b0 values of potassic white micas in low-grade metamorphism of pelitic schists. Tschermaks Min. Petr. Mitt. 18, 108-113.

Schaltegger, U., Gebauer, D. \& von Quadt, A. 2002: The mafic-ultramafic rock association of Loderio-Biasca (lower Pennine nappes, Ticino, Switzerland): Cambrian oceanic magmatism and its bearing on early Paleozoic paleogeography. Chem. Geol. 186, 265-279.

SCHARDT, H. 1906: Die modernen Anschauungen über den Bau und die Entstehung des Alpengebirges. Verh. Schweiz. naturf. Ges., St. Gallen.

SCHMID, S.M., ZINGG, A. \& HANDY, M. 1987: The kinematics of movements along the Insubric Line and the emplacement of the Ivrea Zone. Tectonophysics 135, 47-66.

- RÜCK, P. \& SCHREURs, G. 1990: The significance of the Schams nappes for the reconstruction of the paleotectonic and orogenic evolution of the Penninic zone along the NFP 20-East traverse (Grisons, Eastern Switzerland). In: Deep structure of the Alps. Mém. Soc. géol. France (eds Roure, R., Heitzmann, P. \& Polino, R.). 263-287.

- Pfiffner, O.A., Froitzheim, N., Schönborn, G. \& Kissling, E. 1996: Geophysical-geological transect and tectonic evolution of the Swiss-Italian Alps. Tectonics, 15, 1036-1064.

- Pfiffner, O.A., Schönborn, G., Froitzheim, N. \& Kissling, E. 1997: Integrated cross section and tectonic evolution of the Alps along the eastern traverse. In: NFP 20. Schweizerische Geologische Kommission, Bern, 289-304.

- Fügenschuh, B., Kissling, E. \& Schuster, R. 2004: Tectonic map and overall architecture of the Alpine orogen. Eclogae geol. Helv. 97, 93-117.

SCHMidT, C. 1894: Geologische Exkursionen durch die zentralen Schweizer Alpen. In: Livret Guide géologique Paris - Lausanne. 136-142.

- \& Preiswerk, H. 1908: Spezialkarte Nr. 48: Geologische Karte der Simplongruppe 1:50000. Schweizerische Geologische Kommission. Bern.

SIMPSON, C. 1981: Ductile shear zones: a mechanism of rock deformation in the orthogneisses of the Maggia Nappe, Ticino. Ph.D. Thesis, ETH Zürich, Zürich, 266 pp.

- 1982: The structure of the northern lobe of the Maggia Nappe, Ticino, Switzerland. Eclogae geol. Helv. 75, 495-516.
Simpson, C., WinTSCH, R.P. 1989: Evidence for deformation-induced Kfeldspar replacement by myrmekite. J. metam. Geol., 7, 261-275.

SPEAR, F. S. 1993: Metamorphic phase equilibria and pressure-temperature time-paths. Mineralogical Society of America Monograph. Mineralogical Society of America, Washington D.C. 799 pp.

Spicher, A. 1980: Tektonische Karte der Schweiz 1:500000. Schweizerische Geologische Kommission, Bern.

Stoll, T. 1990: Petrographie und Strukturgeologie um Fusio, Teil 2. Unpublished Diploma Thesis, ETH Zurich, 97 pp.

Staub, R. 1924: Der Bau der Alpen. Beitr. Geol. Karte Schweiz. N.F. 52. Schweizerische Geologische Kommission, Bern, 272 pp.

STECK, A.1968: Junge Bruchsysteme in den Zentralalpen. Eclogae geol. Helv. 61, 387-393.

- 1998: The Maggia cross-fold: An enigmatic structure of the Lower Penninic nappes of the Lepontine Alps. Eclogae geol. Helv. 91, 333-344.

ThakUR, V. C., 1971. The structural and metamorphic history of the Mesozoic and pre-Mesozoic basement rocks of the Molare region, Ticino, Switzerland. $\mathrm{PhD}$ Thesis, Imperial College, London.

ThakUR, V., 1973. Events in Alpine Deformation and Metamorphism in the Northern Pennine Zone and Southern Gotthard Massif Regions, Switzerland. Geol. Rdsch. 62, 549-563.

THOMPSON, P.H. 1976: Isograd pattern and pressure-temperature distribution during regional metamorphism. Contrib. Mineral. Petrol. 57, 277-295.

Timar-Geng, Z., Grujic, D. \& Rahn, M. 2004: Deformation at the Leventina-Simano nappe boundary, Central Alps, Switzerland. Eclogae geol. Helv. 97, 265-278.

TodD, C.S. \& ENGI, M. 1997: Metamorphic field gradients in the Central Alps. J. metam. Geol. 15, 515-530.

WenK, E. 1948: Ostalpines und penninisches Kristallin. Schweiz. Mineral. Petrogr. Mitt. 28, 761-770.

- 1953: Prinzipielles zur geologisch-tektonischen Gliederung des Penninikums im zentralen Tessin. Eclogae geol. Helv. 46, 9-21.

- 1955: Eine Strukturkarte der Tessineralpen. Schweiz. Mineral. Petrogr. Mitt. 35, 311-319.

- 1956: Die lepontinische Gneissregion und die jungen Granite der Valle della Mera. Eclogae geol. Helv. 49, 251-265.

Manuscript received January 29, 2004

Revision accepted February 12, 2005 
